\title{
A Conservative Evaluation of the Transport of TCE from the Confined Aquifer beneath J-Field, Aberdeen Proving Ground, Maryland, to a Hypothetical Receptor
}

Environmental Assessment Division Argonne National Laboratory 


\section{Argonne National Laboratory}

Argonne National Laboratory, with facilities in the states of Illinois and Idaho, is owned by the United States Government, and operated by the University of Chicago under the provisions of a contract with the Department of Energy.

This technical memo is a product of Argonne's Environmental Assessment Division (EAD). For information on the division's scientific and engineering activities, contact:

Director, Environmental Assessment Division

Argonne National Laboratory

Argonne, Illinois 60439-4815

Telephone (630) 252-3107

Presented in this technical memo are preliminary results of ongoing work or work that is more limited in scope and depth than that described in formal reports issued by the EAD.

Publishing support services were provided by Argonne's Information and Publishing Division (for more information, see IPD's home page: http://www.ipd.anl.gov/).

\section{Disclaimer}

This report was prepared as an account of work sponsored by an agency of the United States Government. Neither the United States Government nor any agency thereof, nor any of their employees, makes any warranty, express or implied, or assumes any legal liability or responsibility for the accuracy, completeness, or usefulness of any information, apparatus, product, or process disclosed, or represents that its use would not infringe privately owned rights. Reference herein to any specific commercial product, process, or service by trade name, trademark, manufacturer, or otherwise, does not necessarily constitute or imply its endorsement, recommendation, or favoring by the United States Government or any agency thereof. The views and opinions of authors expressed herein do not necessarily state or reflect those of the United States Government or any agency thereof.

Reproduced directly from the best available copy.

Available to DOE and DOE contractors from the Office of Scientific and Technical Information, P.O. Box 62, Oak Ridge, TN 37831; prices available from (423) $576-8401$

Available to the public from the National Technical Information Service, U.S. Department of Commerce, 5285 Port Royal Road, Springfield, VA 22161. 


\section{A Conservative Evaluation of the Transport of TCE from the Confined Aquifer beneath J-Field, Aberdeen Proving Ground, Maryland, to a Hypothetical Receptor}

by J.J. Quinn, T.L. Patton, and L.E. Martino

Environmental Assessment Division,

Argonne National Laboratory, 9700 South Cass Avenue, Argonne, Illinois 60439

August 1998

Work sponsored by Aberdeen Proving Ground, Directorate of Safety, Health and Environment 
This report is printed on recycled paper. 


\section{Contents}

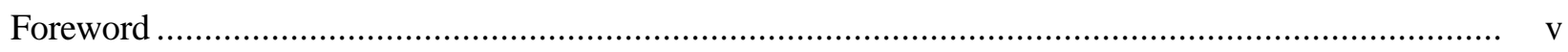

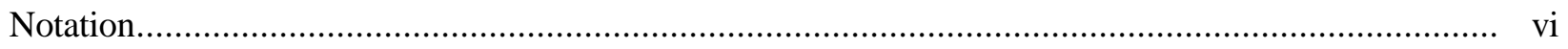

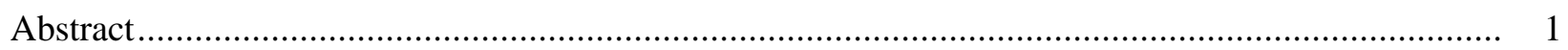

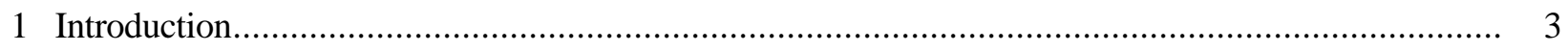

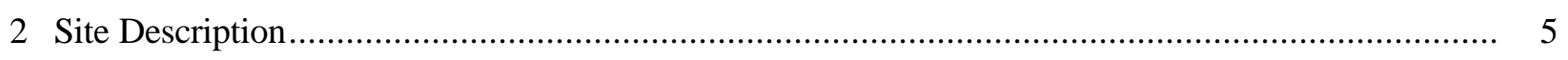

2.1 Local and Regional Hydrogeology ................................................................... 5

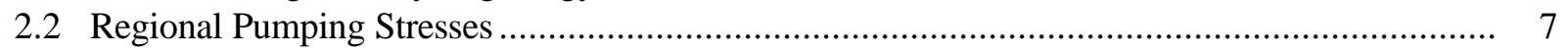

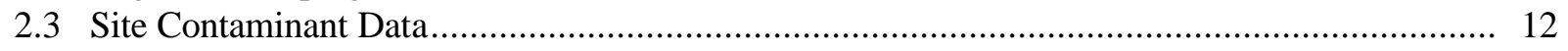

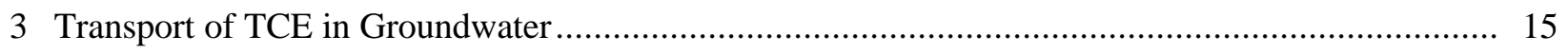

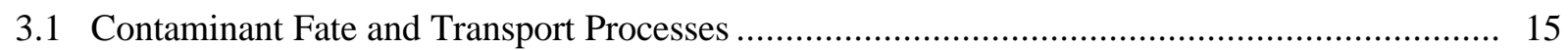

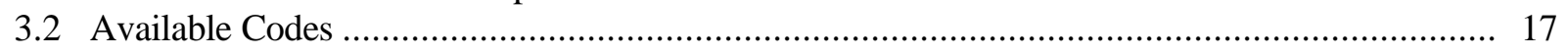

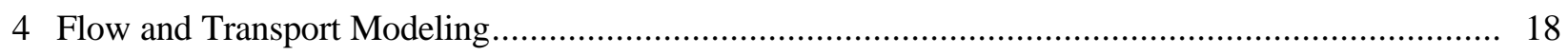

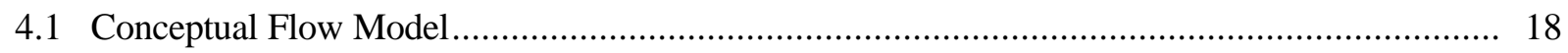

4.2 Numerical Flow Model Setup and Results ................................................................ 18

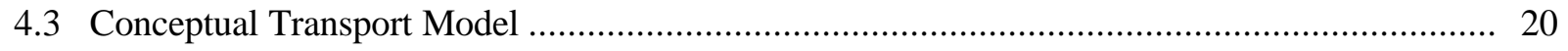

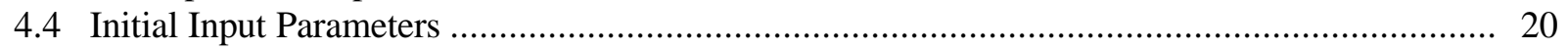

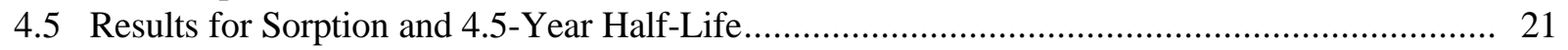

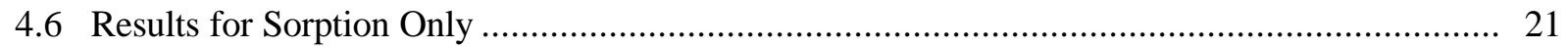

4.7 Results for 4.5-Year Half-Life with No Sorption ........................................................ 22

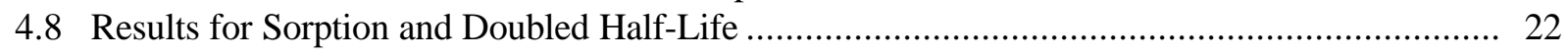

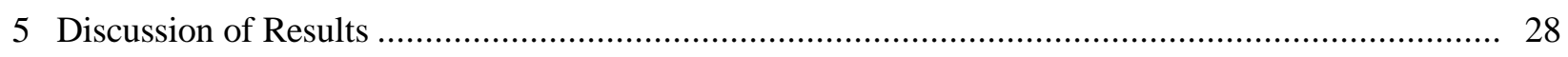

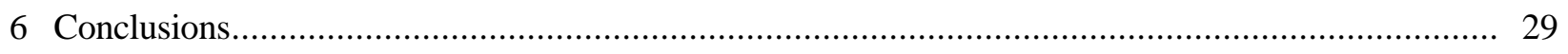

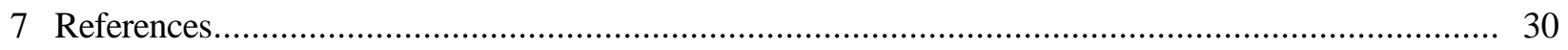




\section{Tables}

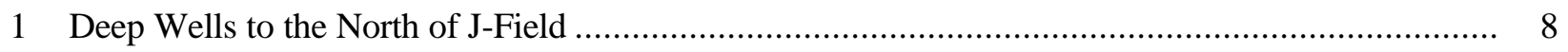

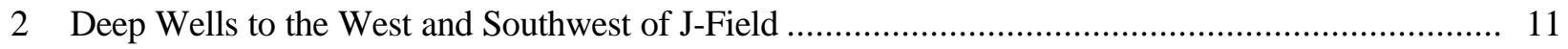

3 Deep Wells to the East and Southeast of J-Field ........................................................... 13

4 TCE Concentrations in Deep Wells of the Toxic Burning Pits Area .......................................... 14

\section{Figures}

1 Locations of J-Field and Pumping Wells in the Region.......................................................... 4

2 Locations of the Toxic Burning Pits Area and Mean 1993 Head Measurements

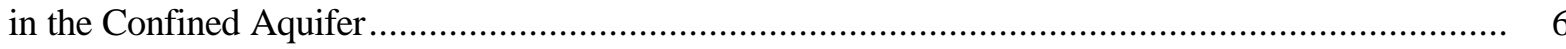

3 Locations of Deep Wells at the Toxic Burning Pits Area.................................................... 14

4 Domain of Flow and Transport Models ......................................................................... 19

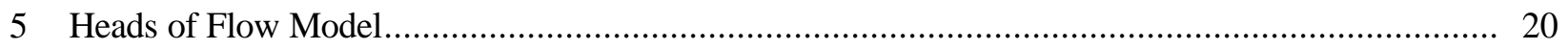

6 Base Case Transport Results for Simulated TCE Concentrations

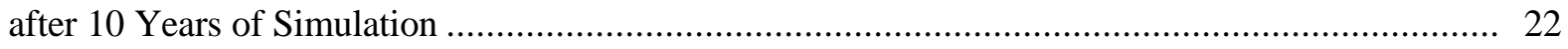

7 Base Case Transport Results for Simulated TCE Concentrations after 20 Years of Simulation

8 Base Case Transport Results for Simulated TCE Concentrations after 30 Years of Simulation

9 Base Case Transport Results for Simulated TCE Concentrations after 40 Years of Simulation

10 Base Case Transport Results for Simulated TCE Concentrations after 50 Years of Simulation

11 Base Case Transport Results for Simulated TCE Concentrations after Reaching Steady State at 60 Years of Simulation. 


\section{Foreword}

This document was prepared by Argonne National Laboratory, Argonne, Illinois, for the Directorate of Safety, Health and Environment, Aberdeen Proving Ground, Maryland. The text of this report has been approved by the U.S. Army for public release and unlimited distribution. The distribution number is OP-SEC Control No. 2725-A-3. 
Notation

The following is a list of the acronyms, initialisms, and abbreviations (including units of measure) used in this document. Some acronyms used in tables or equations are defined only in the respective tables or equations.

\section{Acronyms, Initialisms, and Abbreviations}

$\begin{array}{ll}\text { APG } & \text { Aberdeen Proving Ground } \\ \text { DCE } & \text { dichloroethene } \\ \text { DNAPL } & \text { dense nonaqueous-phase liquid } \\ \text { MSL } & \text { mean sea level } \\ \text { TBP } & \text { Toxic Burning Pits } \\ \text { TCE } & \text { trichloroethylene } \\ \text { VC } & \text { vinyl chloride } \\ \text { VOC } & \text { volatile organic compound }\end{array}$

\section{Units of Measure}

$\begin{array}{ll}\mathrm{d} & \text { day(s) } \\ \mathrm{ft} & \text { foot (feet) } \\ \mathrm{ft}^{3} & \text { cubic foot (feet) } \\ \mathrm{g} & \text { gram(s) } \\ \mathrm{gpm} & \text { gallon(s) per minute } \\ \mathrm{kg} & \text { kilogram(s) } \\ \mathrm{km} & \text { kilometer(s) }\end{array}$

$\begin{array}{ll}\mathrm{L} & \text { liter(s) } \\ \mathrm{lb} & \text { pound(s) } \\ \mathrm{m} & \text { meter(s) } \\ \mu \mathrm{g} & \text { microgram(s) } \\ \mathrm{mi} & \text { mile(s) } \\ \mathrm{mL} & \text { milliliter(s) } \\ \mathrm{ppb} & \text { part(s) per billion } \\ \mathrm{ppm} & \text { part(s) per million }\end{array}$




\section{Abstract}

Past disposal operations at the Toxic Burn Pits (TBP) area of J-Field, Aberdeen Proving Ground, Maryland, have resulted in volatile organic compound (VOC) contamination of groundwater. Although the contaminant concentration is highest in the surficial aquifer, VOCs are also present in the confined aquifer, which is approximately $30 \mathrm{~m}(100 \mathrm{ft})$ deep at the TBP area. This study focuses on the confined aquifer, a sandy valley-fill Pleistocene unit in a paleochannel cut into Cretaceous sands and clays. This report documents the locations of the region's pumping wells, which are over $6 \mathrm{~km}$ (4 mi) away from the TBP. The distances to the pumping wells and the complex stratigraphy limit the likelihood of any contamination reaching a receptor well. Nonetheless, a worst-case scenario was evaluated with a model designed to simulate the transport of trichloroethylene (TCE), the main chemical of concern, from the confined aquifer beneath the TBP along a hypothetical, direct flowpath to a receptor well. The model was designed to be highly conservative (i.e., based on assumptions that promote the transport of contaminants). In addition to the direct flowpath assumption, the model uses the lowest literature value for the biodegradation rate of TCE, a low degree of sorption, a continuous-strength source, and a high flow velocity. Results from this conservative evaluation indicate that the simulated contaminant plume extends into areas offshore from J-Field, but decays before reaching a receptor well. The 5-ppb contour, for example, travels approximately $5 \mathrm{~km}(3 \mathrm{mi})$ before stagnating. Recent field analyses have documented that complete biodegradation of TCE to ethene and ethane is occurring directly below the TBP; therefore, the likelihood of TCE or its daughter products reaching a pumping well appears negligible. Thus, the model results may be useful in proposing either a no action or a natural attenuation alternative for the confined aquifer. 
$\Delta$ 


\section{Section 1 Introduction}

Decades of waste disposal operations have resulted in groundwater contamination at J-Field, Aberdeen Proving Ground (APG), Harford County, Maryland. Although most of the contamination is present in the surficial aquifer, the deeper, confined aquifer also has detectable levels of trichloroethylene (TCE, or TRCLE, or trichloroethene) and other volatile organic compounds (VOCs). The State of Maryland requested an evaluation of the potential risk of these contaminants to residents relying on well water in the region, which prompted this Argonne National Laboratory (ANL) study. The nearest wells are over $6 \mathrm{~km}$ (4 mi) from the Toxic Burning Pits (TBP). These wells are located across the Gunpowder River and Chesapeake Bay (Figure 1). That concentrations at that distance should be negligible seems obvious; however, ANL evaluated the validity of this assumption with groundwater flow and contaminant transport modeling.

The purpose of this modeling effort was to create a one-dimensional flow and transport model for analyzing the potential of contaminant transport from the confined aquifer beneath J-Field to the nearest receptor well. The model was purposefully designed to be highly conservative (i.e., to promote the transport of contaminants). Modeling results will be useful in determining whether natural attenuation or no action are reasonable alternatives for the confined aquifer. 


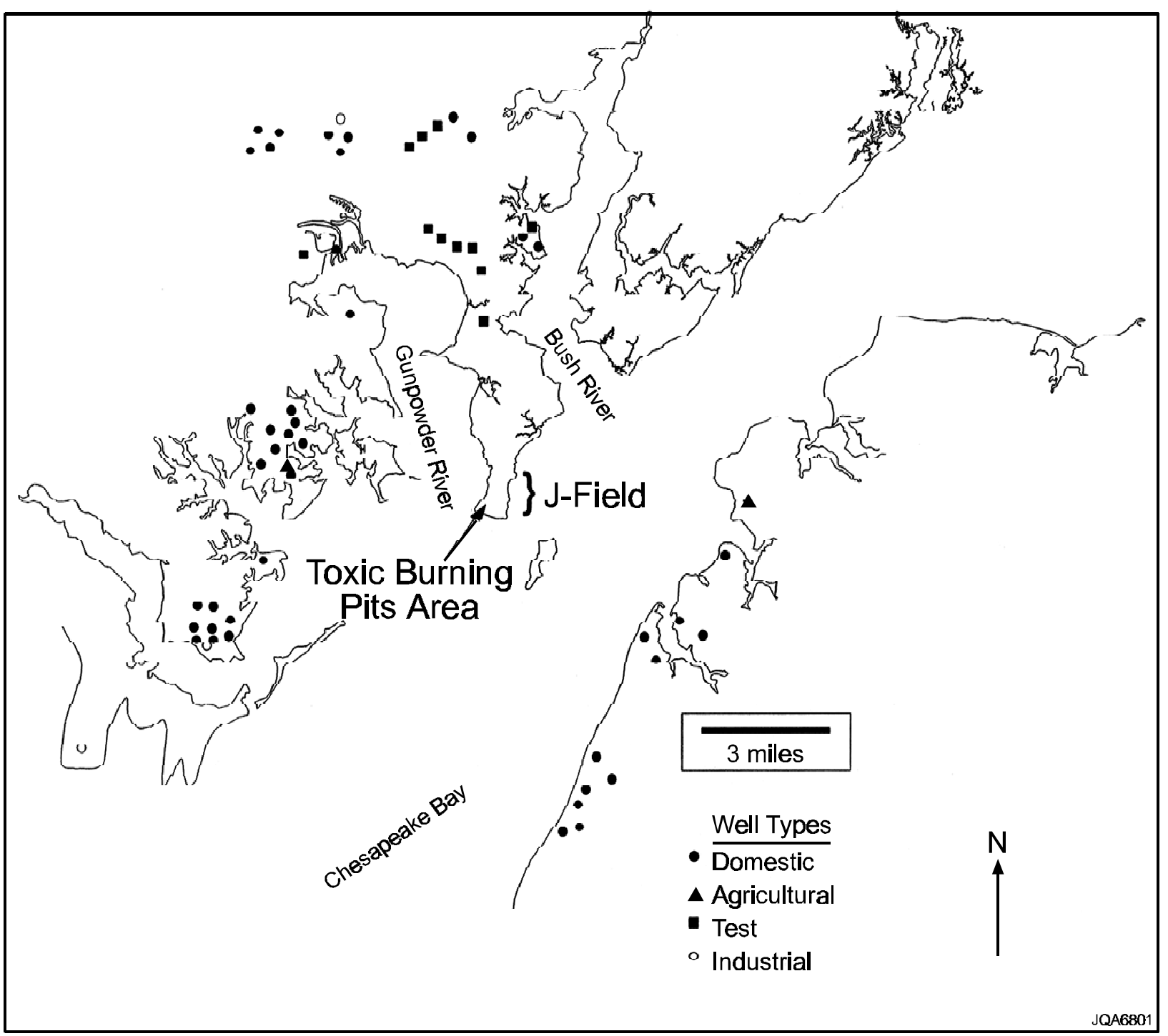

Figure 1 Locations of J-Field and Pumping Wells in the Region 


\section{Section 2 Site Description}

\subsection{Local and Regional Hydrogeology}

The Chesapeake Bay region is underlain by Cretaceous deposits of the Patapsco Formation of the Potomac Group. These sediments form a complex framework of sandy aquifers and massive clay units (Hughes 1993). The coastal Cretaceous deposits were subjected to fluctuating sea levels during the Pleistocene. This resulted in complex erosional and depositional environments, including three main systems of paleochannels cut into the Cretaceous units by the ancient Susquehanna River (Colman et al. 1990). These paleochannels, identified regionally by marine geophysics and drilling records, are present at different depths. Typically, each paleochannel contains infill units of a basal sand and gravel, which grade into the clay and silt of an estuarine deposit. On a regional scale, the stratigraphy is only generally understood from a limited number of boreholes and geophysical surveys. What is known is that a great deal of complexity is present in both the Pleistocene and Cretaceous deposits. Regional cross sections produced by the U.S. Army Corps of Engineers (COE 1997) illustrate the highly variable nature of permeable and impermeable units in the subsurface of the APG region.

The confined aquifer at J-Field is the deepest of three main Pleistocene units of the Talbot Formation that fill a paleochannel (Hughes 1993). The other units are a surficial silty sand aquifer and an intervening fine-grained confining unit. The confined aquifer beneath J-Field is composed of highly permeable sand and gravel at an approximate depth of $30 \mathrm{~m}$ (100 ft) (Hughes 1993). The thickness of this unit in the TBP area ranges from 4 to $15 \mathrm{~m}$ (13 to $50 \mathrm{ft}$ ) (Hughes 1993); its thickness is likely to vary greatly with distance from J-Field. In the immediate vicinity of J-Field, the paleochannel has a northwest to southeast trend. The Cretaceous formations containing the paleochannel deposits include a complex assemblage of sandy and clayey units (Hughes 1993; COE 1997).

Flow in the confined aquifer had been thought to be radial from the J-Field peninsula under low horizontal hydraulic gradients (Hughes 1993). Because of diurnal tidal loading in the confined aquifer (see Hughes 1993, Figure 31), hand measurements of water levels of confined aquifer wells are of limited use. Therefore, continuous recorder data from seven confined aquifer wells at J-Field from the 1993 water year were analyzed to provide a more accurate picture of the overall head distribution (Quinn et al. 1996). The results confirm radial flow (Figure 2). The greatest average horizontal hydraulic gradient indicated by these heads is $3.4 \times 10^{-4}$ between wells JF61 and JF41. The gradients decrease closer to the shore.

Where the paleochannel extends beneath the Chesapeake Bay, groundwater probably discharges upward to the bay (Hughes 1993; Powars 1997). The rate of discharge is most likely minimal because of the low hydraulic conductivity of the overlying confining unit 


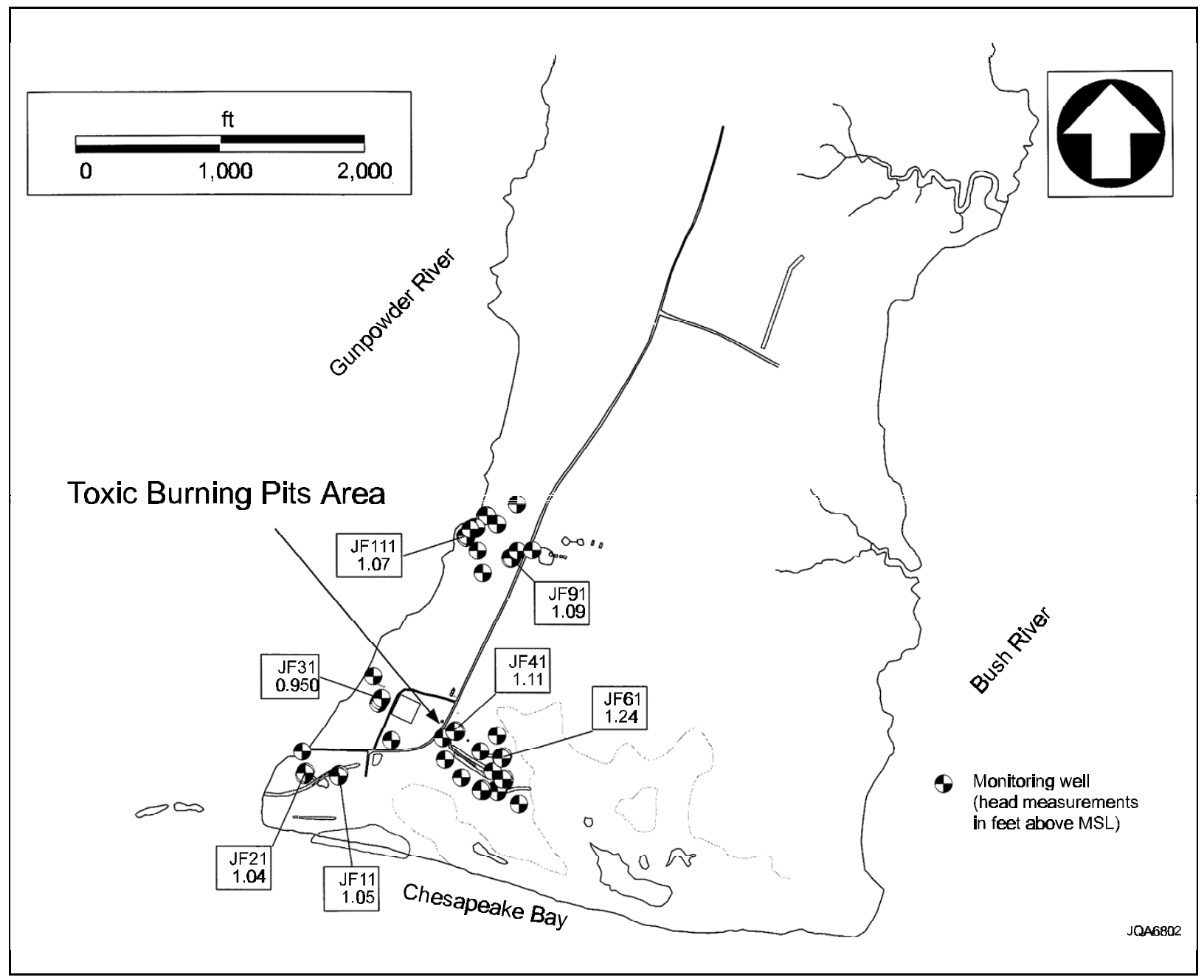

Figure 2 Locations of the Toxic Burning Pits Area and Mean 1993 Head Measurements in the Confined Aquifer

and the low vertical head gradient across the confining unit (Hughes 1993). The degree of connection between the confined aquifer and any permeable portions of the Cretaceous units along the paleochannel wall has not been established.

Because the timing and magnitude of the tidal loading effect are independent of position relative to the J-Field shore, it is assumed to have no impact on lateral groundwater flow within the confined aquifer.

In the deeper Cretaceous sediments, most of the regional flow from the portions of Maryland on the western and eastern shores of the bay discharges slowly to the bay (Otton and Mandle 1984). Flow within the Cretaceous units is primarily in poorly connected sand bodies, and the connections between these sands are not clearly understood because of considerable spatial variation (Otton and Mandle 1984). Even at 
the scale of site-specific investigations, the Cretaceous sand/clay architecture is difficult to decipher (Hughes 1993; Tenbus and Fleck 1996).

Slug tests performed on four monitoring wells in the confined aquifer at J-Field provided a range of hydraulic conductivity values from $1.1 \times 10^{-3}$ to $3.2 \times 10^{-1}$ (3 to $900 \mathrm{ft} / \mathrm{d}$ ) (Hughes 1993). The lower values at two wells represented a portion of the aquifer with a relatively high silt and clay content; values from the other two wells represent sand zones.

Drummond and Blomquist (1993) compiled hydraulic conductivity information on Cretaceous coastal plain aquifers in Harford County. A range from $2.1 \times 10^{-3}$ to $3.1 \times 10^{-1}$ (6 to $870 \mathrm{ft} / \mathrm{d})$ is presented, with a median of $3.0 \times 10^{-1}(85 \mathrm{ft} / \mathrm{d})$.

\subsection{Regional Pumping Stresses}

To evaluate possible regional influences of pumping wells on the confined aquifer beneath J-Field, a survey of wells within a 13.7-km (8.5-mi) radius of J-Field (measured from the southern tip of Rickett's Point Road) was conducted. Because of the depth of the confined aquifer at J-Field, shallow wells (those less than approximately $27 \mathrm{~m}$ [90 ft] deep) were ignored in the survey, since they are not likely to have a strong connection to the deeper groundwater flow system. Locations of deep wells in the survey are shown in Figure 1.

Well applications processed since 1969 for designated areas and well completion reports were obtained from the Groundwater Permits Program, Maryland Department of Environment, Baltimore, Maryland. General information pertaining to production at well fields was obtained from Drummond and Blomquist (1993).

The wells were placed into three groups on the basis of their location relative to J-Field. To the north, the major pumping centers are associated with the towns of Edgewood and Joppatowne and primarily service domestic and small commercial users (Table 1). The largest pumping center in Harford County is the well field at Perryman, $11 \mathrm{~km}(7 \mathrm{mi})$ to the northeast of Edgewood, which produced an average of $11.7 \mathrm{million} \mathrm{L} / \mathrm{d}$ (3.1 million gal/d) in 1989 from the Potomac Group sediments. The town of Aberdeen produced an average of 4.9 million L/d (1.3 million gal/d) from two well fields in 1989 . Pumping at the Edgewood Area of APG was negligible in 1989.

The pumping centers to the west and southwest of J-Field service primarily domestic, agricultural, and small commercial users (Table 2). Most of these wells were completed at depths less than $27 \mathrm{~m}$ (90 ft), with a range from 4 to $208 \mathrm{~m}$ (14 to $684 \mathrm{ft})$; six wells (3 domestic, 2 industrial, and 1 agricultural) are greater than $52 \mathrm{~m}(170 \mathrm{ft})$. The largest pumping center is Bethlehem Steel Corp., $19 \mathrm{~km}$ (12 mi) to the west-southwest, which

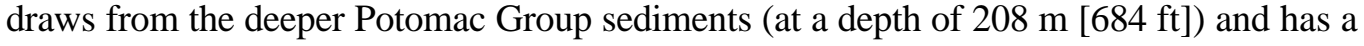
capacity of about 4.5 million L/d (1.2 million gal/d). 
Table 1 Deep Wells to the North of J-Field

\begin{tabular}{|c|c|c|c|c|}
\hline No. & Well ID & $\begin{array}{c}\text { Depth/Screen }^{\mathrm{a}} \\
\text { (unit, description) }^{\mathrm{a}}\end{array}$ & $\begin{array}{c}\text { Distance from } \\
\text { J-Field } \\
\text { (to nearest half mile) }\end{array}$ & Type (capacity) \\
\hline 1 & GA-72-0166 & $113 \mathrm{ft}$ & $6.5 \mathrm{mi} \mathrm{N}-\mathrm{NE}$ & Domestic (15 gpm, test) \\
\hline 2 & HA-81-3019 & $145 \mathrm{ft}$ & $6.5 \mathrm{mi} \mathrm{N}-\mathrm{NE}$ & $\begin{array}{l}\text { Test (1 gpm, test) } \\
\text { U.S. Army }\end{array}$ \\
\hline $3^{\mathrm{b}}$ & HA-81-3020 & $\begin{array}{l}170 \mathrm{ft} / 160-165 \mathrm{ft} \\
\text { (Patapsco, sand and } \\
\text { gravel under clay) }\end{array}$ & $6.5 \mathrm{mi} \mathrm{N}-\mathrm{NE}$ & $\begin{array}{l}\text { Test (1 gpm, test) } \\
\text { U.S. Army }\end{array}$ \\
\hline 4 & HA-81-1166 & $107 \mathrm{ft}$ & $6.5 \mathrm{mi} \mathrm{N}-\mathrm{NE}$ & Domestic (20 gpm, test) \\
\hline 5 & HA-81-1616 & $88 \mathrm{ft}$ & $4.5 \mathrm{mi} \mathrm{N}$ & $\begin{array}{l}\text { Test (1 gpm, test) } \\
\text { Commander, APG }\end{array}$ \\
\hline 6 & HA-81-2989 & $145 \mathrm{ft}$ & $6.5 \mathrm{mi} \mathrm{N}-\mathrm{NW}$ & $\begin{array}{l}\text { Test (1 gpm, test) } \\
\text { U.S. Army }\end{array}$ \\
\hline 7 & HA-81-2990 & $180 \mathrm{ft}$ & $6.5 \mathrm{mi} \mathrm{N}-\mathrm{NW}$ & $\begin{array}{l}\text { Test (1 gpm, test) } \\
\text { U.S. Army }\end{array}$ \\
\hline 8 & HA-81-4078 & $95 \mathrm{ft}$ & $6.0 \mathrm{mi} \mathrm{N}-\mathrm{NW}$ & $\begin{array}{l}\text { Test (1 gpm, test) } \\
\text { U.S. Army }\end{array}$ \\
\hline 9 & HA-81-2997 & $99 \mathrm{ft}$ & $6.0 \mathrm{mi} \mathrm{N}-\mathrm{NW}$ & $\begin{array}{l}\text { Test (1 gpm, test) } \\
\text { U.S. Army }\end{array}$ \\
\hline 10 & HA-81-3005 & $90 \mathrm{ft}$ & $6.0 \mathrm{mi} \mathrm{N}-\mathrm{NW}$ & $\begin{array}{l}\text { Test (1 gpm, test) } \\
\text { U.S. Army }\end{array}$ \\
\hline 11 & HA-81-3006 & $107 \mathrm{ft}$ & $6.0 \mathrm{mi} \mathrm{N}-\mathrm{NW}$ & $\begin{array}{l}\text { Test (1 gpm, test) } \\
\text { U.S. Army }\end{array}$ \\
\hline 12 & HA-81-1494 & $139 \mathrm{ft}$ & $5.5 \mathrm{mi} \mathrm{N}$ & $\begin{array}{l}\text { Test (1 gpm, test) } \\
\text { U.S. Army }\end{array}$ \\
\hline 13 & HA-81-4167 & $140 \mathrm{ft}$ & $8.0 \mathrm{~m} \mathrm{~N}-\mathrm{NW}$ & $\begin{array}{l}\text { Test (50 gpm, test) } \\
\text { Harford Co. DPW }\end{array}$ \\
\hline 14 & $\mathrm{HA}-81-4166$ & $157 \mathrm{ft}$ & $8.0 \mathrm{~N}-\mathrm{NW}$ & $\begin{array}{l}\text { Test (162 gpm, test) } \\
\text { Harford Co. DPW }\end{array}$ \\
\hline
\end{tabular}


Table 1 Deep Wells to the North of J-Field (Cont.)

\begin{tabular}{|c|c|c|c|c|}
\hline No. & Well ID & $\begin{array}{c}\text { Depth/Screen } \\
\text { (unit, description) }^{\mathrm{a}}\end{array}$ & $\begin{array}{c}\text { Distance from } \\
\text { J-Field } \\
\text { (to nearest half mile) }\end{array}$ & Type (capacity) \\
\hline 15 & $\mathrm{HA}-81-4130$ & $150 \mathrm{ft}$ & $8.5 \mathrm{mi} \mathrm{N}-\mathrm{NW}$ & $\begin{array}{l}\text { Test (15 gpm, test) } \\
\text { Maryland Geological Survey }\end{array}$ \\
\hline 16 & GA-73-0774 & $130 \mathrm{ft}$ & $8.5 \mathrm{mi} \mathrm{N}$ & Domestic (10 gpm, test) \\
\hline 17 & GA-73-1260 & $138 \mathrm{ft}$ & $8.5 \mathrm{mi} \mathrm{N}$ & Domestic (10 gpm, test) \\
\hline 18 & $\mathrm{HA}-81-2452$ & $125 \mathrm{ft}$ & $8.5 \mathrm{mi} \mathrm{N}-\mathrm{NE}$ & Domestic (20 gpm, test) \\
\hline 19 & BA-81-4948 & $100 \mathrm{ft}$ & $7.5 \mathrm{mi} \mathrm{N}-\mathrm{NW}$ & $\begin{array}{l}\text { Test (1 gpm, test) } \\
\text { Enviro-Gro Tech }\end{array}$ \\
\hline 20 & HA-73-5234 & $100 \mathrm{ft}$ & $7.5 \mathrm{mi} \mathrm{N}-\mathrm{NW}$ & Domestic (7 gpm, test) \\
\hline 21 & BA-81-4357 & $150 \mathrm{ft}$ & $9.5 \mathrm{mi} \mathrm{N}-\mathrm{NW}$ & Domestic (15 gpm, test) \\
\hline 22 & BA-88-2088 & $300 \mathrm{ft}$ & $9.0 \mathrm{mi} \mathrm{N}-\mathrm{NW}$ & Domestic ( no data) \\
\hline 23 & BA-73-6603 & $127 \mathrm{ft}$ & $9.5 \mathrm{mi} \mathrm{N}-\mathrm{NW}$ & Domestic (12 gpm, test) \\
\hline 24 & HA-70-0399 & $100 \mathrm{ft}$ & 9.5 mi N-NW & Domestic (3 gpm, test) \\
\hline 25 & HA-72-0355 & $170 \mathrm{ft}$ & $9.5 \mathrm{mi} \mathrm{N}-\mathrm{NW}$ & Domestic (15 gpm, test) \\
\hline 26 & HA-73-0239 & $236 \mathrm{ft}$ & $9.5 \mathrm{mi} \mathrm{N}-\mathrm{NW}$ & Domestic (4 gpm, test) \\
\hline 27 & HA-73-5109 & $150 \mathrm{ft}$ & 9.5 mi N-NW & Domestic (2 gpm, test) \\
\hline 28 & HA-73-5341 & $275 \mathrm{ft}$ & 9.5 mi N-NW & Domestic (12 gpm, test) \\
\hline 29 & HA-73-5446 & $325 \mathrm{ft}$ & $9.5 \mathrm{mi} \mathrm{N}-\mathrm{NW}$ & Domestic (2 gpm, test) \\
\hline 30 & HA-73-5865 & $300 \mathrm{ft}$ & $9.5 \mathrm{mi} \mathrm{N}-\mathrm{NW}$ & Domestic (6 gpm, test) \\
\hline 31 & HA-73-5950 & $250 \mathrm{ft}$ & $9.5 \mathrm{mi} \mathrm{N}-\mathrm{NW}$ & Domestic (7 gpm, test) \\
\hline 32 & HA-81-1465 & $250 \mathrm{ft}$ & $9.5 \mathrm{mi} \mathrm{N}-\mathrm{NW}$ & Domestic (12 gpm, test) \\
\hline 33 & BA-92-0930 & $200 \mathrm{ft}$ & $9.5 \mathrm{mi} \mathrm{N}-\mathrm{NW}$ & Domestic (5 gpm, test) \\
\hline 34 & HA-70-0352 & $355 \mathrm{ft}$ & $9.5 \mathrm{mi} \mathrm{N}-\mathrm{NW}$ & Domestic ( $6 \mathrm{gpm}$, test) \\
\hline
\end{tabular}


Table 1 Deep Wells to the North of J-Field (Cont.)

\begin{tabular}{|c|c|c|c|c|}
\hline No. & Well ID & $\begin{array}{c}\text { Depth/Screen }^{\mathrm{a}} \\
\text { (unit, description) }^{\mathrm{a}}\end{array}$ & $\begin{array}{c}\text { Distance from } \\
\text { J-Field } \\
\text { (to nearest half mile) }\end{array}$ & Type (capacity) \\
\hline 35 & HA-71-0497 & $142 \mathrm{ft}$ & $9.5 \mathrm{mi} \mathrm{N}-\mathrm{NW}$ & Domestic (30 gpm, test) \\
\hline 36 & HA-72-0418 & $290 \mathrm{ft}$ & $9.5 \mathrm{mi} \mathrm{N}-\mathrm{NW}$ & Domestic (50 gpm, test) \\
\hline 37 & HA-73-0610 & $207 \mathrm{ft}$ & $9.5 \mathrm{mi} \mathrm{N}-\mathrm{NW}$ & Domestic (5 gpm, test) \\
\hline 38 & HA-73-1764 & $250 \mathrm{ft}$ & $9.5 \mathrm{mi} \mathrm{N}-\mathrm{NW}$ & Domestic (20 gpm, test) \\
\hline $39^{\mathrm{b}}$ & HA-73-1774 & $\begin{array}{c}375 \mathrm{ft} / 100-375 \mathrm{ft} \\
\text { (Patapsco, hard grey rock) }\end{array}$ & $9.5 \mathrm{mi} \mathrm{N}-\mathrm{NW}$ & Domestic (30 gpm, test) \\
\hline 40 & HA-73-2060 & $275 \mathrm{ft}$ & $9.5 \mathrm{mi} \mathrm{N}-\mathrm{NW}$ & Domestic (6 gpm, test) \\
\hline 41 & HA-73-2123 & $150 \mathrm{ft}$ & $9.5 \mathrm{mi} \mathrm{N}-\mathrm{NW}$ & Domestic (15 gpm, test) \\
\hline $42^{b}$ & HA-73-4585 & $\begin{array}{c}350 \mathrm{ft} / 85-350 \mathrm{ft} \\
\text { (Patapsco, black rock) }\end{array}$ & 9.5 mi N-NW & Industrial (2 gpm, test) \\
\hline 43 & HA-73-4789 & $105 \mathrm{ft}$ & $9.5 \mathrm{mi} \mathrm{N}-\mathrm{NW}$ & Domestic (7 gpm, test) \\
\hline 44 & HA-81-1002 & $135 \mathrm{ft}$ & $9.0 \mathrm{mi} \mathrm{N}-\mathrm{NW}$ & Domestic (7 gpm, test) \\
\hline 45 & HA-81-2373 & $200 \mathrm{ft}$ & $9.0 \mathrm{mi} \mathrm{N}-\mathrm{NW}$ & Domestic (7 gpm, test) \\
\hline 46 & BA-81-2872 & $90 \mathrm{ft}$ & $5.5 \mathrm{mi} \mathrm{N}-\mathrm{NW}$ & Domestic (30 gpm, test) \\
\hline
\end{tabular}

a If available.

b Well completion reports obtained for these wells include a well log and the results of a pumping test.

To the east and southeast, across Chesapeake Bay, the pumping centers service primarily domestic and agricultural users (Table 3). Most of these wells were completed at depths less than $27 \mathrm{~m}(90 \mathrm{ft})$, with a range from 4 to $60 \mathrm{~m}(24 \mathrm{ft}$ to $196 \mathrm{ft})$; two domestic wells are greater than $58 \mathrm{~m}(190 \mathrm{ft})$ deep. The average daily quantities needed for these wells are generally less than 3,800 L/d (1,000 gal/d); the application record for one agricultural well reports a capacity of $270,000 \mathrm{~L} / \mathrm{d}(72,000 \mathrm{gal} / \mathrm{d})$.

Pumping stresses have a negligible effect on the confined aquifer at J-Field because of the distances involved and the complex stratigraphy. Even at the Graces Quarters portion of APG, located northwest of J-Field across the Gunpowder River, the influence of unknown off-site pumping wells on a confined Cretaceous aquifer is minimal (Tenbus and Fleck 1996). 
Table 2 Deep Wells to the West and Southwest of J-Field

\begin{tabular}{|c|c|c|c|c|}
\hline No. & Well ID & $\begin{array}{c}\text { Depth/Screen }^{\mathrm{a}} \\
\text { (unit, description) }^{\mathrm{a}}\end{array}$ & $\begin{array}{c}\text { Distance from } \\
\text { J-Field } \\
\text { (to nearest half mile) } \\
\end{array}$ & Type (capacity) \\
\hline $1^{\mathrm{b}}$ & BA-81-3199 & $\begin{array}{l}225 \mathrm{ft} / 215-225 \mathrm{ft} \\
\text { (Patapsco, fine sand under } \\
\text { sand and white clay) }\end{array}$ & $5.5 \mathrm{mi} \mathrm{W}-\mathrm{SW}$ & $\begin{array}{l}\text { Domestic }(7 \mathrm{gpm}, \text { test }) \\
\mathrm{ADQN}^{\mathrm{C}}=1,000 \mathrm{gal} / \mathrm{d}\end{array}$ \\
\hline $2^{\mathrm{b}}$ & BA-81-2741 & $\begin{array}{l}684 \mathrm{ft} / 640-684 \mathrm{ft} \\
\text { (Patapsco, green clay and } \\
\text { rock under coarse white } \\
\text { sand and mixed clays) }\end{array}$ & $12.0 \mathrm{mi} \mathrm{W}-\mathrm{SW}$ & $\begin{array}{l}\text { Industrial ( } 800 \mathrm{gpm} \text {, test) } \\
\text { Bethlehem Steel Corp. }\end{array}$ \\
\hline 3 & BA-81-5684 & $110 \mathrm{ft}$ & $6.0 \mathrm{mi} \mathrm{W}-\mathrm{NW}$ & Domestic (7 gpm, test) \\
\hline 4 & BA-73-6521 & $100 \mathrm{ft}$ & $6.0 \mathrm{mi} \mathrm{W}-\mathrm{NW}$ & Domestic (5 gpm, test) \\
\hline 5 & BA-81-0550 & $130 \mathrm{ft}$ & $5.5 \mathrm{mi} \mathrm{W}-\mathrm{NW}$ & Domestic (7 gpm, test) \\
\hline 6 & BA-88-0164 & $125 \mathrm{ft}$ & $5.5 \mathrm{mi} \mathrm{W}-\mathrm{NW}$ & Domestic (7 gpm, test) \\
\hline $7^{\mathrm{b}}$ & BA-92-0595 & $\begin{array}{c}173 \mathrm{ft} / 166-173 \mathrm{ft} \\
\text { (Patapsco, sand under red } \\
\text { clay) }\end{array}$ & $5.0 \mathrm{mi} \mathrm{W}-\mathrm{NW}$ & Domestic (7 gpm, test) \\
\hline 8 & BA-73-2658 & $130 \mathrm{ft}$ & $5.0 \mathrm{mi} \mathrm{W}-\mathrm{NW}$ & Domestic (7 gpm, test) \\
\hline 9 & BA-81-5445 & $140 \mathrm{ft}$ & $5.0 \mathrm{mi} \mathrm{W}-\mathrm{NW}$ & Domestic (7 gpm, test) \\
\hline 10 & BA-93-0154 & $139 \mathrm{ft}$ & $5.0 \mathrm{mi} \mathrm{W}-\mathrm{NW}$ & Domestic (7 gpm, test) \\
\hline 11 & BA-73-7197 & $135 \mathrm{ft}$ & $5.5 \mathrm{mi} \mathrm{W}-\mathrm{NW}$ & Domestic (7 gpm, test) \\
\hline 12 & BA-88-0946 & $100 \mathrm{ft}$ & $5.5 \mathrm{mi} \mathrm{W}-\mathrm{NW}$ & Domestic (7 gpm, test) \\
\hline $13^{b}$ & BA-81-1897 & $\begin{array}{l}250 \mathrm{ft} / 240-250 \mathrm{ft} \\
\text { (Patapsco, sand and clay } \\
\text { under white clay) }\end{array}$ & $5.0 \mathrm{mi} \mathrm{W}-\mathrm{NW}$ & Farm (100 gpm, test) \\
\hline 14 & BA-73-6219 & $145 \mathrm{ft}$ & $5.0 \mathrm{mi} \mathrm{W}-\mathrm{NW}$ & Domestic (25 gpm, test) \\
\hline 15 & BA-81-8538 & $110 \mathrm{ft}$ & $7.5 \mathrm{mi} \mathrm{W}-\mathrm{SW}$ & Domestic (7 gpm, test) \\
\hline 16 & BA-73-1758 & $100 \mathrm{ft}$ & $7.5 \mathrm{mi} \mathrm{W}-\mathrm{SW}$ & Domestic (25 gpm, test) \\
\hline $17^{\mathrm{b}}$ & BA-71-0115 & $\begin{array}{c}223 \mathrm{ft} / 218-223 \mathrm{ft} \\
\text { (Patapsco, coarse sand } \\
\text { under white clay) }\end{array}$ & $7.5 \mathrm{mi} \mathrm{W}-\mathrm{SW}$ & $\begin{array}{l}\text { Industrial (5 gpm, test) } \\
\text { Recreation and Parks }\end{array}$ \\
\hline 18 & BA-72-0638 & $125 \mathrm{ft}$ & $7.5 \mathrm{mi} \mathrm{W}-\mathrm{SW}$ & Domestic (40 gpm, test) \\
\hline 19 & BA-73-0359 & $125 \mathrm{ft}$ & $7.5 \mathrm{mi} \mathrm{W}-\mathrm{SW}$ & Domestic (20 gpm, test) \\
\hline 20 & BA-73-6256 & $107 \mathrm{ft}$ & $7.5 \mathrm{mi} \mathrm{W}-\mathrm{SW}$ & $\begin{array}{l}\text { Industrial (20 gpm, test) } \\
\text { Baltimore Co. }\end{array}$ \\
\hline
\end{tabular}


Table 2 Deep Wells to the West and Southwest of J-Field (Cont.)

\begin{tabular}{|c|c|c|c|c|}
\hline No. & Well ID & $\begin{array}{c}\text { Depth/Screen }^{\mathrm{a}} \\
\text { (unit, description) }^{\mathrm{a}}\end{array}$ & $\begin{array}{c}\text { Distance from } \\
\text { J-Field } \\
\text { (to nearest half mile) }\end{array}$ & Type (capacity) \\
\hline $21^{\mathrm{b}}$ & BA-81-3783 & $\begin{array}{c}205 \mathrm{ft} / 195-205 \mathrm{ft} \text { (Patapsco, } \\
\text { sand under sand and white } \\
\text { clay) }\end{array}$ & $7.0 \mathrm{mi} \mathrm{W}-\mathrm{SW}$ & Domestic (12 gpm, test) \\
\hline 22 & BA-81-1172 & $130 \mathrm{ft}$ & $7.5 \mathrm{mi} \mathrm{W}-\mathrm{SW}$ & Domestic (50 gpm, test) \\
\hline 23 & BA-81-1262 & $110 \mathrm{ft}$ & $7.5 \mathrm{mi} \mathrm{W}-\mathrm{SW}$ & $\begin{array}{l}\text { Industrial ( } 45 \mathrm{gpm} \text {, test) } \\
\text { Baltimore Co. }\end{array}$ \\
\hline 24 & BA-81-5817 & $120 \mathrm{ft}$ & $7.0 \mathrm{mi} \mathrm{W}-\mathrm{SW}$ & Domestic (7 gpm, test) \\
\hline 25 & BA-81-3468 & $107 \mathrm{ft}$ & $7.0 \mathrm{mi} \mathrm{W}-\mathrm{SW}$ & Domestic (40 gpm, test) \\
\hline 26 & BA-81-0734 & $125 \mathrm{ft}$ & $7.0 \mathrm{mi} \mathrm{W}-\mathrm{SW}$ & Domestic (7 gpm, test) \\
\hline
\end{tabular}

a If available.

b Well completion reports obtained for these wells include a well log and the results of a pumping test.

c $\mathrm{ADQN}=$ average daily quantity needed.

\subsection{Site Contaminant Data}

TCE and other VOCs have been detected in confined aquifer wells JF51, JF61, JF71, and JF81 (Table 4 and Figure 3), although an inspection of the well construction and stratigraphy presented in Hughes (1993) indicates that only well JF81 is screened in the permeable confined aquifer sediments. The TCE concentrations range from 1.8 to $1,600 \mathrm{ppb}$ in these wells. The TCE regulatory limit in drinking water is $5 \mathrm{ppb}$ according to Maryland Code of Regulations 26.04.01.07.

When concentrations of chlorinated solvents dissolved in groundwater exceed $1 \%$ of their solubility, the presence of a dense nonaqueous-phase liquid (DNAPL) is suggested (Remediation Technologies Development Forum 1996). Because the solubility of TCE is about $1,100 \mathrm{ppm}$, the maximum detected is only $0.15 \%$ of the solubility, which suggests that pure DNAPL is not present in the samples collected. 
Table 3 Deep Wells to the East and Southeast of J-Field

\begin{tabular}{|c|c|c|c|c|}
\hline No. & Well ID & $\begin{array}{c}\text { Depth/Screen } \\
\text { (Unit, Description) }^{\mathrm{a}}\end{array}$ & $\begin{array}{c}\text { Distance from } \\
\text { J-Field } \\
\text { (to nearest half mile) }\end{array}$ & Type (Capacity) \\
\hline $1^{\mathrm{b}}$ & KE-81-0515 & $\begin{array}{c}103 \mathrm{ft} / 93-103 \mathrm{ft} \text { (Patapsco, } \\
\text { dark brown sand under } \\
\text { green sand and shells }\end{array}$ & $6.0 \mathrm{mi} \mathrm{E}-\mathrm{SE}$ & $\begin{array}{l}\text { Domestic }(10 \mathrm{gpm}, \text { test }) \\
\mathrm{ADQN}^{\mathrm{C}}=300 \mathrm{gal} / \mathrm{day}\end{array}$ \\
\hline 2 & KE-81-0166 & $97 \mathrm{ft}$ & $5.5 \mathrm{mi}$ E-SE & Domestic (20 gpm, test) \\
\hline 3 & KE-81-0575 & $90 \mathrm{ft}$ & $5.0 \mathrm{mi}$ E-SE & Domestic (30 gpm, test) \\
\hline 4 & KE-73-0752 & $196 \mathrm{ft}$ & $6.0 \mathrm{mi} \mathrm{E}-\mathrm{SE}$ & Domestic (40 gpm, test) \\
\hline 5 & KE-81-0394 & $190 \mathrm{ft}$ & $6.0 \mathrm{mi} \mathrm{E}-\mathrm{SE}$ & $\begin{array}{l}\text { Farm (50 gpm, test) } \\
\text { Andelot Farms }\end{array}$ \\
\hline $6^{b}$ & KE-73-0120 & $\begin{array}{c}92 \mathrm{ft} / 84-92 \mathrm{ft} \\
\text { (Talbot, fine to medium grey } \\
\text { clay) }\end{array}$ & $6.5 \mathrm{mi} \mathrm{S}-\mathrm{SE}$ & $\begin{array}{l}\text { Domestic }(10 \mathrm{gpm}, \text { test }) \\
\mathrm{ADQN}=1,000 \mathrm{gal} / \mathrm{day}\end{array}$ \\
\hline 7 & KE-81-0232 & $105 \mathrm{ft}$ & $6.5 \mathrm{mi} \mathrm{S}-\mathrm{SE}$ & Domestic (30 gpm, test) \\
\hline 8 & KE-81-1255 & $100 \mathrm{ft}$ & $7.0 \mathrm{mi} \mathrm{S}-\mathrm{SE}$ & Domestic (15 gpm, test) \\
\hline $9^{b}$ & KE-81-1470 & $\begin{array}{c}114 \mathrm{ft} / 104-114 \mathrm{ft} \\
\text { (Patapsco, white fine to } \\
\text { coarse sand? under grey } \\
\text { clay) }\end{array}$ & $7.0 \mathrm{mi} \mathrm{S}$-SE & Domestic (60 gpm, test) \\
\hline 10 & KE-81-0402 & $95 \mathrm{ft}$ & $6.5 \mathrm{mi} \mathrm{S}-\mathrm{SE}$ & Domestic (15 gpm, test) \\
\hline 11 & KE-81-1001 & $93 \mathrm{ft}$ & $6.0 \mathrm{mi} \mathrm{S}-\mathrm{SE}$ & Domestic (100 gpm, test) \\
\hline 12 & KE-81-0731 & $88 \mathrm{ft}$ & $6.0 \mathrm{mi} \mathrm{E}-\mathrm{SE}$ & Domestic (35 gpm, test) \\
\hline
\end{tabular}

a If available.

b Well completion reports obtained for these wells include a well log and the results of a pumping test.

c $\mathrm{ADQN}=$ average daily quantity needed. 
Table 4 TCE Concentrations in Deep Wells of the Toxic Burning Pits Area

\begin{tabular}{|ccccc|}
\hline & \multicolumn{4}{c}{ Well } \\
\cline { 2 - 5 } & JF51 & JF61 & JF71 & JF81 \\
\cline { 2 - 5 } & \multicolumn{4}{c}{ Hydrogeologic Unit } \\
\cline { 2 - 5 } & Primarily & Primarily & Primarily & \\
Hydrogeologic Unit & $\begin{array}{c}\text { Confining } \\
\text { Unit }\end{array}$ & $\begin{array}{c}\text { Confining } \\
\text { Unit }\end{array}$ & $\begin{array}{c}\text { Confining } \\
\text { Unit }\end{array}$ & $\begin{array}{c}\text { Confined } \\
\text { Aquifer }\end{array}$ \\
\hline 1990 TCE samples (ppb) & 520 & 1.8 & 7.3 & 230 \\
1992 TCE samples (ppb) & 97 & 10 & 3 & 220 \\
1994 TCE samples $(\mathrm{ppb})$ & 850 & 6 & ND $^{\mathrm{a}}$ & 1,600 \\
\hline
\end{tabular}

a ND = not detected.

Source: unpublished Argonne National Laboratory data.
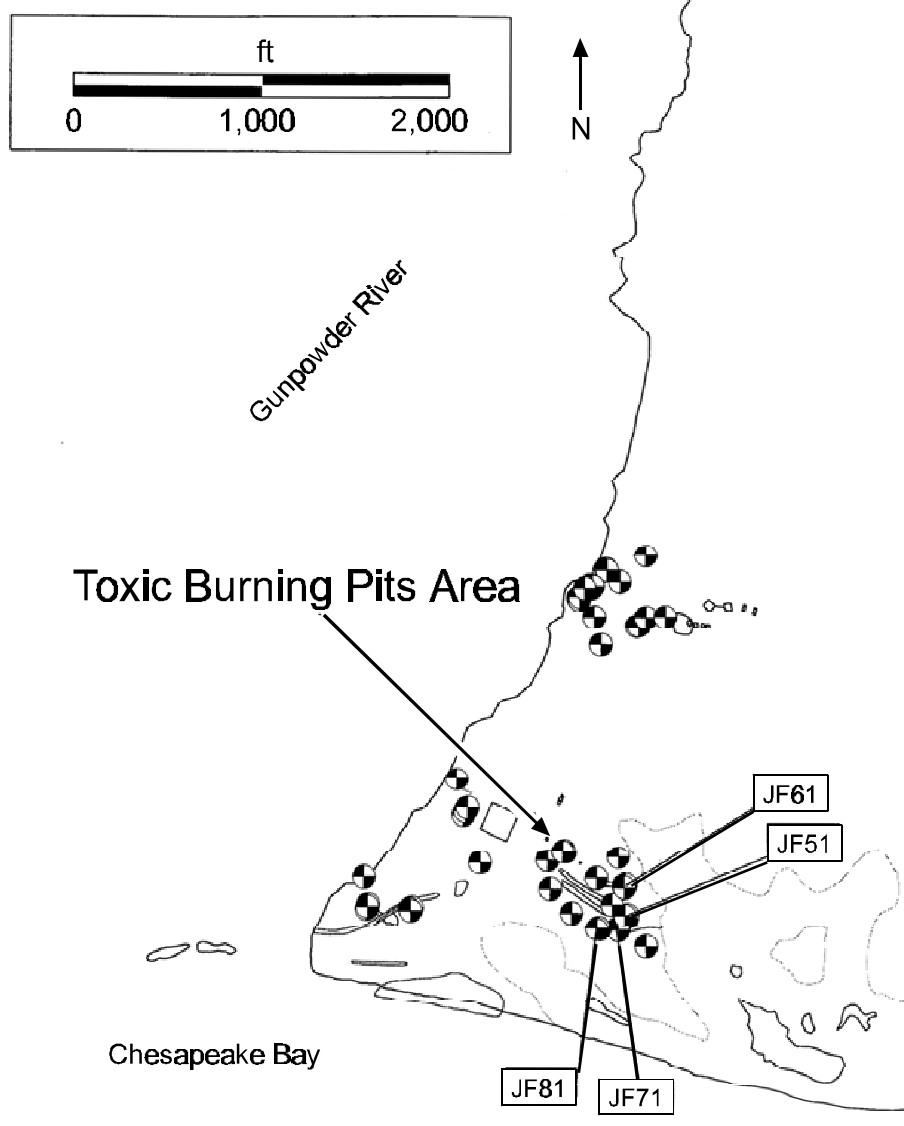

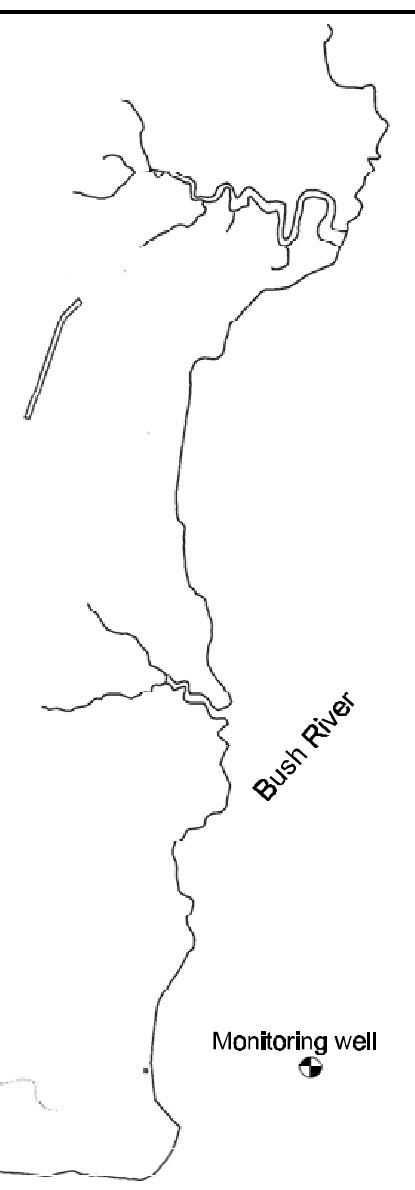

Figure 3 Locations of Deep Wells at the Toxic Burning Pits Area 


\section{Section 3 Transport of TCE in Groundwater}

\subsection{Contaminant Fate and Transport Processes}

The rate of contaminant transport in groundwater is governed by many factors, including advection, dispersion, diffusion, dilution, retardation, and decay. Advection is the movement of dissolved contaminants along with the bulk groundwater flow. During advection, molecules spread both along and perpendicular to the flow direction, a process called dispersion. Diffusion of contaminants is typically a very slow process that occurs along a concentration gradient. The combination of advection, dispersion, and diffusion results in dilution of the contaminant.

Retardation is a slowing of the transport of contaminants relative to the bulk groundwater flow rate as the result of sorption of the contaminants onto aquifer matrix material. Sorption depends on the type of contaminant, the aquifer mineralogy, and the presence of organic matter in the aquifer matrix. Sorption of contaminants is normally described with a distribution coefficient, $K_{d}$, as shown in the following equation:

$$
K_{d}=C_{s} / C_{a q}
$$

where:

$$
\begin{aligned}
K_{d}= & \text { distribution coefficient (length/mass } \left.\left[\mathrm{L}^{3} / \mathrm{M}\right]\right) ; \\
C_{S}= & \text { mass of solute sorbed per dry unit weight of solid }(\mathrm{M} / \mathrm{M}) ; \text { and } \\
C_{a q}= & \begin{array}{l}
\text { concentration of solute in solution in equilibrium with the mass of solute } \\
\text { sorbed onto the solid }\left(\mathrm{M} / \mathrm{L}^{3}\right) .
\end{array}
\end{aligned}
$$

The $K_{d}$ is determined on the basis of the partition coefficient of the chemical with respect to organic carbon by the following relationship:

$K_{d}=\left(K_{o c}\right)\left(f_{o c}\right)$

where:

$$
\begin{aligned}
K_{O c} & =\text { partition coefficient with respect to organic carbon }\left(\mathrm{L}^{3} / \mathrm{M}\right) ; \text { and } \\
f_{o c} & =\text { organic carbon fraction of the aquifer (unitless). }
\end{aligned}
$$

The value of $K_{o c}$ for TCE normally ranges from approximately 40 to $200 \mathrm{~mL} / \mathrm{g}$ (Fetter 1993; Mackay et al. 1993). Pankow and Cherry (1996) provide examples of 
$f_{o c}$ values, ranging from 0.0001 to 0.0075 , in various sandy aquifers. Zheng and Bennett (1995) provide a range of $f_{o c}$ values in glaciofluvial sands from 0.00017 to 0.00102 .

Below a critical value for $f_{o c}$, the organic chemical is sorbed primarily onto the aquifer's mineral matter, rather than onto its organic matter. When $f_{o c}$ is below this critical value, the $K_{d}$ value may be underestimated by the above equation, as sorption to mineral surfaces begins to dominate. For TCE, Fetter (1993) proposed a critical $f_{o c}$ value of 0.0007 .

The $K_{d}$ value affects the retardation, $R$, of the contaminant by the relationship

$$
R=1+\left(K_{d}\right)\left(B_{d}\right) / n
$$

where:

$$
\begin{aligned}
R & =\text { retardation (unitless); } \\
B_{d} & =\text { bulk density }\left(\mathrm{M} / \mathrm{L}^{3}\right) ; \text { and } \\
n & =\text { porosity (unitless). }
\end{aligned}
$$

Retardation, $R$, is the ratio of the rate of bulk groundwater flow to the rate of contaminant transport. Pankow and Cherry (1996) describe TCE retardation factors at several sandy aquifers in North America. Values are generally less than 10 and usually between 1 and 2.5 .

The use of $K_{d}$ values is a simplifying approach to a complex process. A limitation of the method is that, by using a linear isotherm, the model does not limit the amount of solute that can be sorbed (Fetter 1993).

The decay due to biodegradation of a VOC such as TCE can be modeled in an approximate fashion by using a half-life approach. In this manner, a first-order rate of degradation of the compound due to biochemical processes governs the amount of parent chemical mass remaining.

TCE biodegrades in the aquifer environment, but its rate of natural degradation depends on subsurface conditions, including the type and prevalence of microbial populations, and whether aerobic or anaerobic conditions are present. TCE degrades to cis-1,2-dichloroethylene, with lesser amounts of trans-1,2-dichloroethylene and 1,1-dichloroethylene in an anaerobic environment (Barbee 1994). The isomers of dichloroethene (DCE) further degrade to vinyl chloride (VC). VC is commonly believed to degrade to ethene only under aerobic conditions; however, this process has also been known to occur under anaerobic conditions in a laboratory (DiStefano et al. 1991; deBruin et al. 1992; Wu et al. 1995). The ethene is further degraded to ethane (deBruin et al. 1992). Complete degradation from TCE to ethene and ethane has also been observed in the field (Cox et al. 1995; Lee et al. 1995). 
Co-metabolism is the conversion of a chlorinated compound to another chemical by microorganisms during growth on other carbon compounds. In an aerobic environment, TCE can be co-metabolized along with methane, alkenes, aromatic compounds, or ammonia (Remediation Technologies Development Forum 1996). In an anaerobic situation, TCE can be co-metabolized under conditions of denitrification, sulfate reduction, and methanogenesis (Remediation Technologies Development Forum 1996).

Degradation of TCE depends on site-specific factors, including redox conditions, and decay may not follow a simple first-order model. Limited literature on the half-life estimated for TCE indicates a wide range of half-life values. Howard et al. (1991) estimated that the half-life of TCE in groundwater ranges from 10.7 months, on the basis of hydrolysis, to 4.5 years on the basis of anaerobic sediments. In the Netherlands, Zoeteman et al. (1981) estimated a half-life of 2.0 years in groundwater. Yeh and Kastenberg (1991) estimated 86 days. Cohen and Mercer (1993) provided a range of half-lives in groundwater from 321 to 1,653 days. Barbee (1994) estimated a half-life of 33 to 230 days for anaerobic degradation. A compilation of seven field-scale case studies of TCE half-lives by Wiedemeier et al. (1996) shows a range of values from 0.3 to 4.2 years.

\subsection{Available Codes}

Several codes are available for modeling natural attenuation processes in groundwater. BIOPLUME II (Rifai et al. 1989) is a two-dimensional U.S. Environmental Protection Agency (EPA) code for handling oxygen-limited biodegradation.

BIOSCREEN 3D (Newell et al. 1996) handles not only oxygen, but also biodegradation under the influences of other chemicals. BIOMOD 3-D (Draper Aden Environmental Modeling, Inc. 1996) couples to flow output from the U.S. Geological Survey flow model MODFLOW (McDonald and Harbaugh 1988) to simulate degradation of up to five species through first-order, oxygen-limited, anaerobic or Monod kinetics schemes, and sequential anaerobic or first-order biodegradation of daughter products. MT3D (Zheng 1992) and RT3D (Clement 1997) can also be used with a MODFLOW flow model to simulate contaminant transport and biodegradation. MT3D models sorption and can be used to characterize biodegradation in a simple fashion by using a first-order decay term. RT3D, which is an enhancement of MT3D, simulates multispecies reactive transport, including degradation with complex reaction kinetics.

For the current study, few biodegradation-related data are available for the confined aquifer. No clear upgradient/downgradient relationships are established for confined aquifer wells, and no concentration targets can be determined for calibration purposes. For these reasons, detailed biodegradation modeling was not a reasonable option for purposes of this study. MT3D was selected to model conservative degrees of sorption and simple first-order degradation along a conservative, hypothetical flow path to a well. 


\section{Section 4 \\ Flow and Transport Modeling}

\subsection{Conceptual Flow Model}

While the confined aquifer is believed to be a sandy deposit in a paleochannel, the extent and variable thickness of the aquifer are uncertain, as is the degree of hydraulic connection between the confined aquifer and permeable portions of the paleochannel walls. Although valuable data have been collected, any conceptual model of the confined aquifer will have a large degree of uncertainty because of the complex hydrogeological framework. The lack of a suitable conceptual model prohibited the construction of a detailed two- or three-dimensional flow and transport model.

A flowpath from the confined aquifer beneath J-Field to pumping wells in the region may not exist. However, to evaluate a worst-case hydrogeological situation, a simple, highly conservative flow model was designed. The modeling was simplified into a one-dimensional domain (Figure 4) representing flow conservatively assumed to travel directly from the confined aquifer beneath the TBP area to a hypothetical receptor well $8 \mathrm{~km}(5 \mathrm{mi})$ away. The hypothetical flowpath includes J-Field's confined aquifer (Pleistocene Talbot Formation) and permeable portions of the Cretaceous Patapsco Formation aquifer.

The direct flowpath assumption is especially conservative because (1) it ignores regional flow directions and actually could simulate flow in a direction opposite of the actual flow; (2) it ignores complex, three-dimensional flow paths that groundwater would have to follow while within the paleochannel, at the wall of the paleochannel, and within the permeable zones of the Cretaceous sediments; and (3) it ignores upward discharge to the bay.

\subsection{Numerical Flow Model Setup and Results}

Boundary conditions for this flowpath promote a fast rate of travel. A constant head value of $0.34 \mathrm{~m}(1.1 \mathrm{ft}) \mathrm{MSL}$ was assigned to the TBP area, in agreement with the mean water level of confined aquifer wells (Quinn et al. 1996). Pumping stresses are not modeled explicitly. At the downgradient end, a constant head value of $-3 \mathrm{~m}(-10 \mathrm{ft})$ MSL was assigned to force a high hydraulic gradient across the modeling domain. The $-3 \mathrm{~m}(-10 \mathrm{ft})$ MSL value is lower than that suggested in regional modeling of pumping stresses in the Patapsco aquifer (Fleck and Vroblesky 1996; Tenbus and Fleck 1996). Because of the model's boundary conditions, the calculated heads are independent of values for thickness and hydraulic conductivity. However, these values are required as input to the model, and the hydraulic conductivity value affects the flow rate. A confined aquifer thickness of $9 \mathrm{~m}(30 \mathrm{ft})$ was assigned on the basis of confined aquifer data 


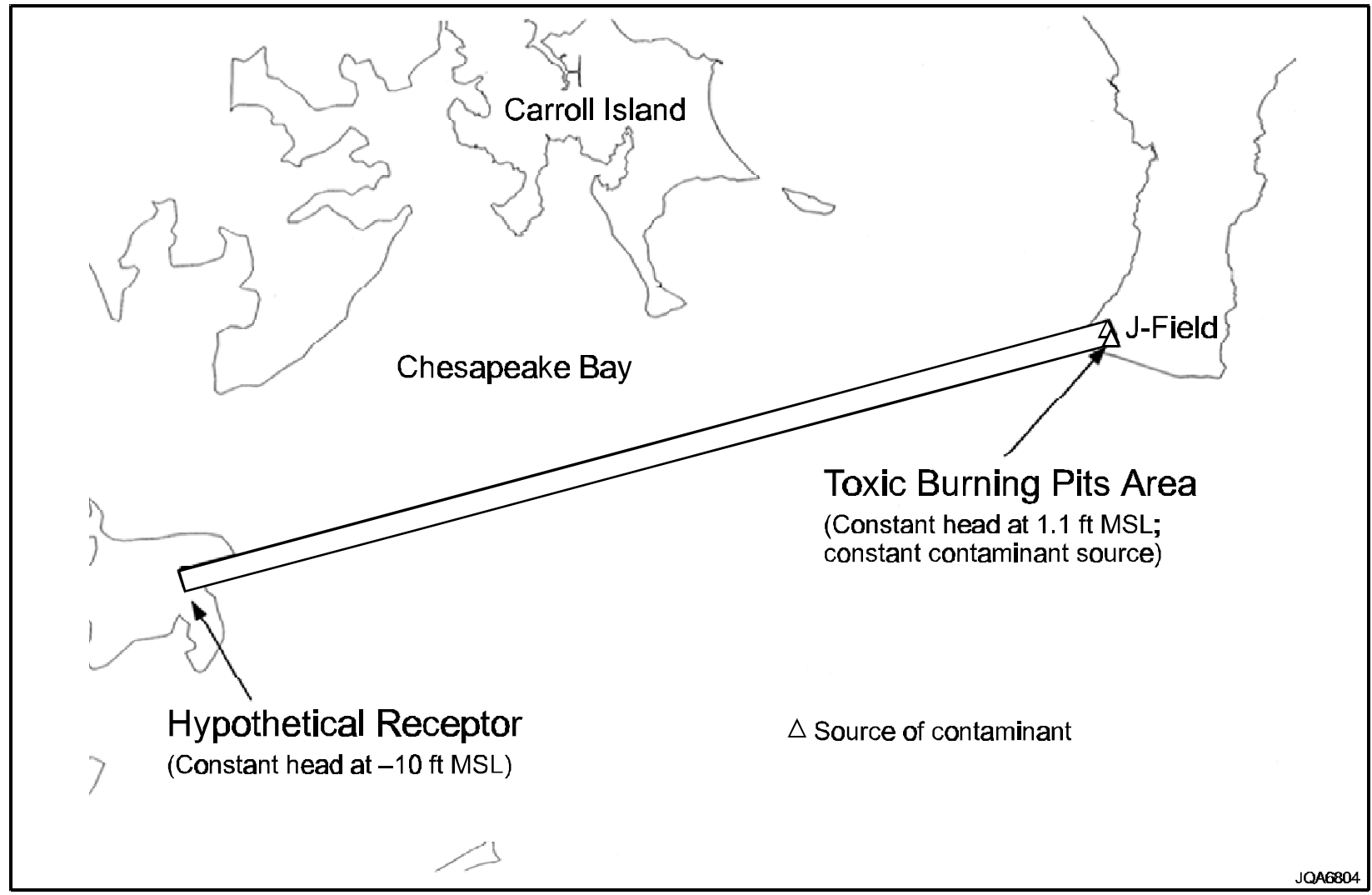

Figure 4 Domain of Flow and Transport Models

compiled by Hughes (1993). The hydraulic conductivity was set to the highest measured value at J-Field, a value of $274 \mathrm{~m} / \mathrm{d}(900 \mathrm{ft} / \mathrm{d})$ (Hughes 1993).

In area, the model grid covers $8,382 \times 152 \mathrm{~m}(27,500 \times 500 \mathrm{ft})$. The model was expanded from one row to two to facilitate contouring. In the direction of flow are 550 columns, each $15 \mathrm{~m}(50 \mathrm{ft})$ wide. The narrow width reduces numerical dispersion in the transport simulations.

Results of the flow model indicate linearly decreasing heads from the TBP area to the receptor well (Figure 5). This conservative flow field was used as input in the transport model. 


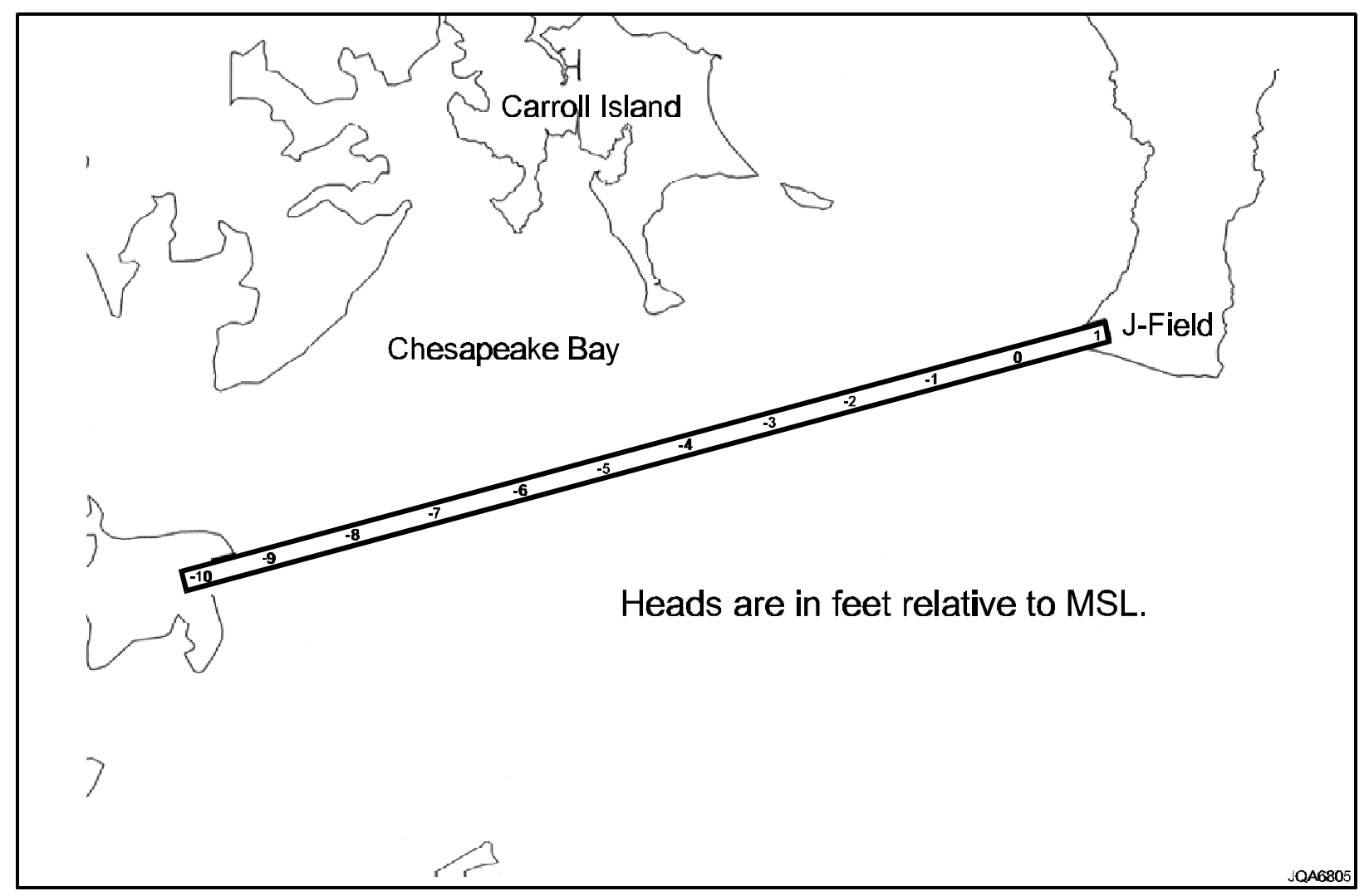

Figure 5 Heads of Flow Model

\subsection{Conceptual Transport Model}

TCE was selected as the primary contaminant of concern. This selection did not involve a detailed study of DNAPL migration from near-surface TBP sources downward through the confining unit, but rather an analysis of dissolved-phase TCE beginning in the confined aquifer. In addition to the direct flowpath assumption, other conservative assumptions included in the transport model were a high hydraulic gradient, high porosity, low attenuation, and no dilution along the flow path.

\subsection{Initial Input Parameters}

The MT3D simulations rely on the flow field generated by the MODFLOW flow model as the advective component of transport. For simplicity, dispersion was considered negligible. The effective porosity of the aquifer was assumed to be 0.3 , and the bulk density was assumed to be $1,860 \mathrm{~kg} / \mathrm{m}^{3}\left(116 \mathrm{lb} / \mathrm{ft}^{3}\right)$. These values have not been measured but should be within $15 \%$ of actual values. They are, therefore, not considered to be major sources of error.

Because the confined aquifer is an anaerobic environment (Target Environmental Services, Inc. 1998), biodegradation of VOCs is assumed to occur along the hypothetical 
flowpath. Drummond and Blomquist (1993) suggest the presence of anaerobic conditions in the deep aquifers of the region. Recent site-specific data indicate that the confined aquifer at J-Field is an anaerobic environment with natural attenuation processes likely degrading TCE to ethene and ethane (Target Environmental Services, Inc. 1998). In the model, TCE was assumed to biodegrade under these anaerobic conditions on the basis of the slowest half-life reported in the literature, 4.5 years (Howard et al. 1991; Cohen and Mercer 1993).

Sorption of TCE was assumed to occur following a linear sorption model. The lowest value of $K_{O C}$ in the literature, $40 \mathrm{~mL} / \mathrm{g}$ (Mackay et al. 1993), was combined with an $f_{o c}$ of 0.001 in the range of values provided by Pankow and Cherry (1996). Although no site-specific $f_{o c}$ data are available, Powars (1997) noted visible organic matter in the confined aquifer and in portions of the Cretaceous sands. The selected $K_{o c}$ and $f_{o c}$ values resulted in a $K_{d}$ of $0.04 \mathrm{~L}^{3} / \mathrm{kg}\left(6.4 \times 10^{-4} \mathrm{ft}^{3} / \mathrm{lb}\right)$, or a retardation of 1.25 , which is near the low end of literature values for TCE (Pankow and Cherry 1996).

Two conservative assumptions were made concerning the contaminant source in the model. First, the source assigned to the upgradient end of the model was conservatively given the concentration of $1,600 \mu \mathrm{g} / \mathrm{L}$, the maximum measured value. Second, the source was specified as constant over time.

In addition to a base case using the above input values, several other scenarios were modeled to evaluate the sensitivity of selected input parameters. Each simulation covered 100 years; calculated concentrations were saved at 10-year intervals.

\subsection{Results for Sorption and 4.5-Year Half-Life (Base Case)}

The base case for analysis of the confined aquifer below the TBP included the conservative degrees of sorption and biodegradation, as discussed above. The results indicated that the zone of high contaminant levels does not extend as far as the hypothetical receptor (Figures 6 to 11). As a result of the first-order decay, the 5-ppb contour stabilized $3.2 \mathrm{~km}$ ( $2 \mathrm{mi}$ ) from the receptor in less than 50 years. Even the 1-ppb contour stabilized in less than 70 years. Despite the small cell size, the results were affected by a low degree of numerical dispersion (discussed below), which would extend the plume, in keeping with the conservative design of this study.

\subsection{Results for Sorption Only}

This scenario was analyzed primarily to determine the effect of numerical dispersion on results. Because no decay or hydraulic dispersion was modeled, the theoretical results should represent a sharp concentration front. Modeled results showed a reasonably low degree of numerical dispersion because the concentration front was fairly narrow. 


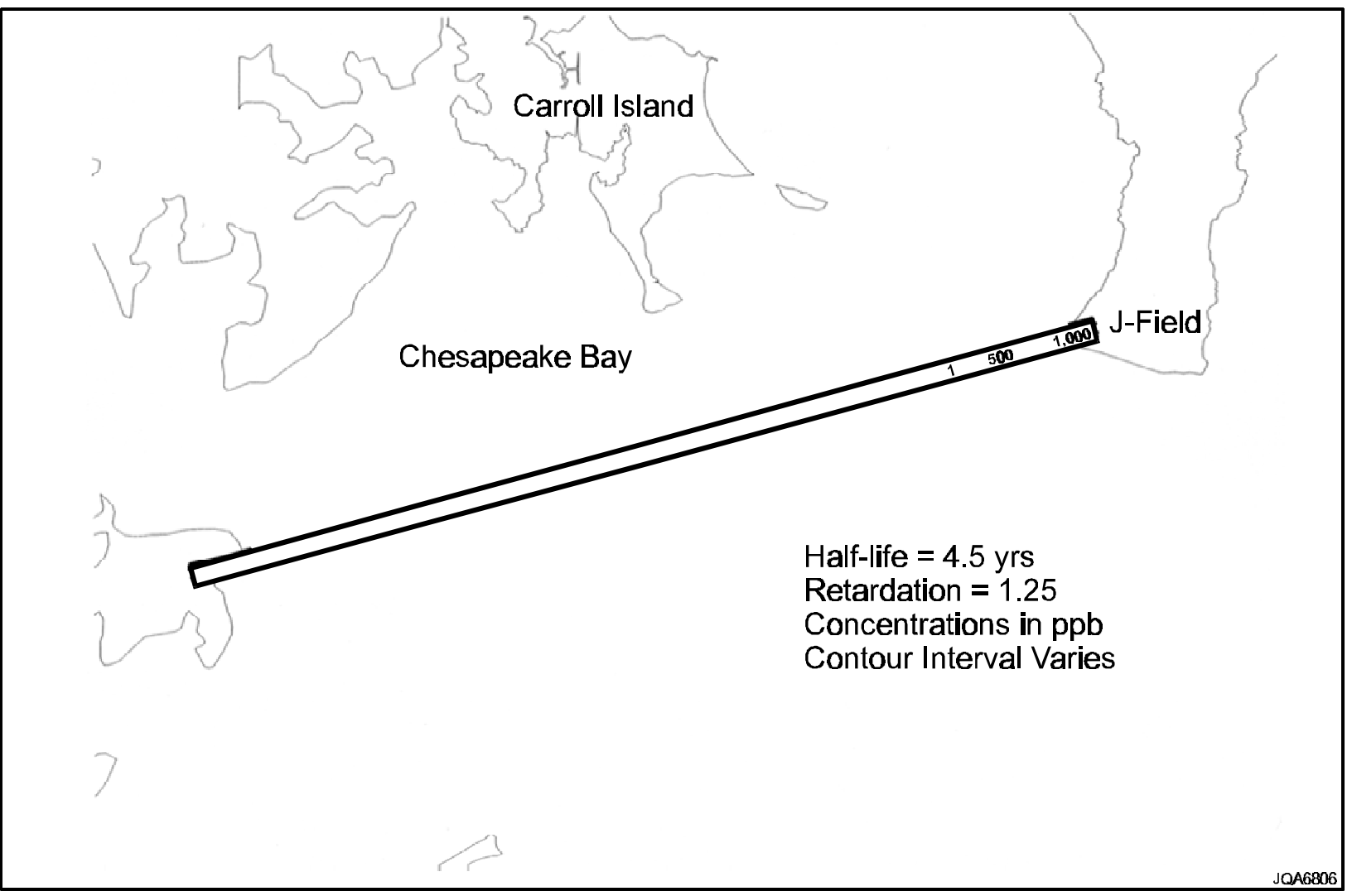

Figure 6 Base Case Transport Results for Simulated TCE Concentrations after 10 Years of Simulation

\subsection{Results for 4.5-Year Half-Life with No Sorption}

Because $R$ is 1.25 in the base case, the results for this scenario simply showed the plume traveling $25 \%$ faster and extending $25 \%$ farther with no retardation $\left(K_{d}=0\right.$; therefore, $R=1$ ).

\subsection{Results for Sorption and Doubled Half-Life}

With a half-life of 9 years (double the highest value in the literature), the decay rate was half that of the base case. The results for this scenario showed the 1- through 10-ppb contours reaching the receptor after approximately 75 years. The bulk of the plume, however, should stabilize in 60 years; the 50-ppb contour should be over $1.6 \mathrm{~km}(1 \mathrm{mi})$ from the receptor. 


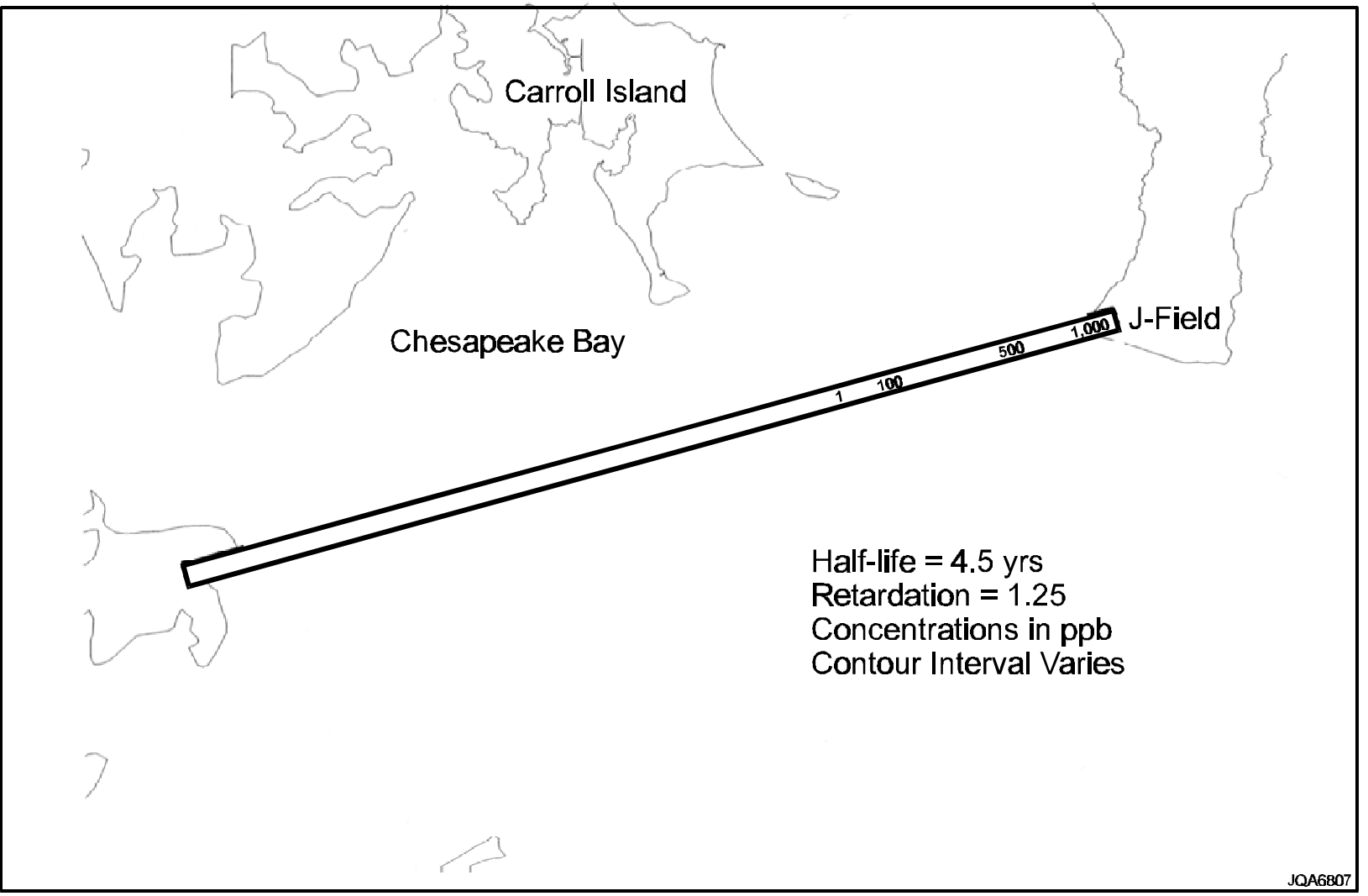

Figure 7 Base Case Transport Results for Simulated TCE Concentrations after 20 Years of Simulation 


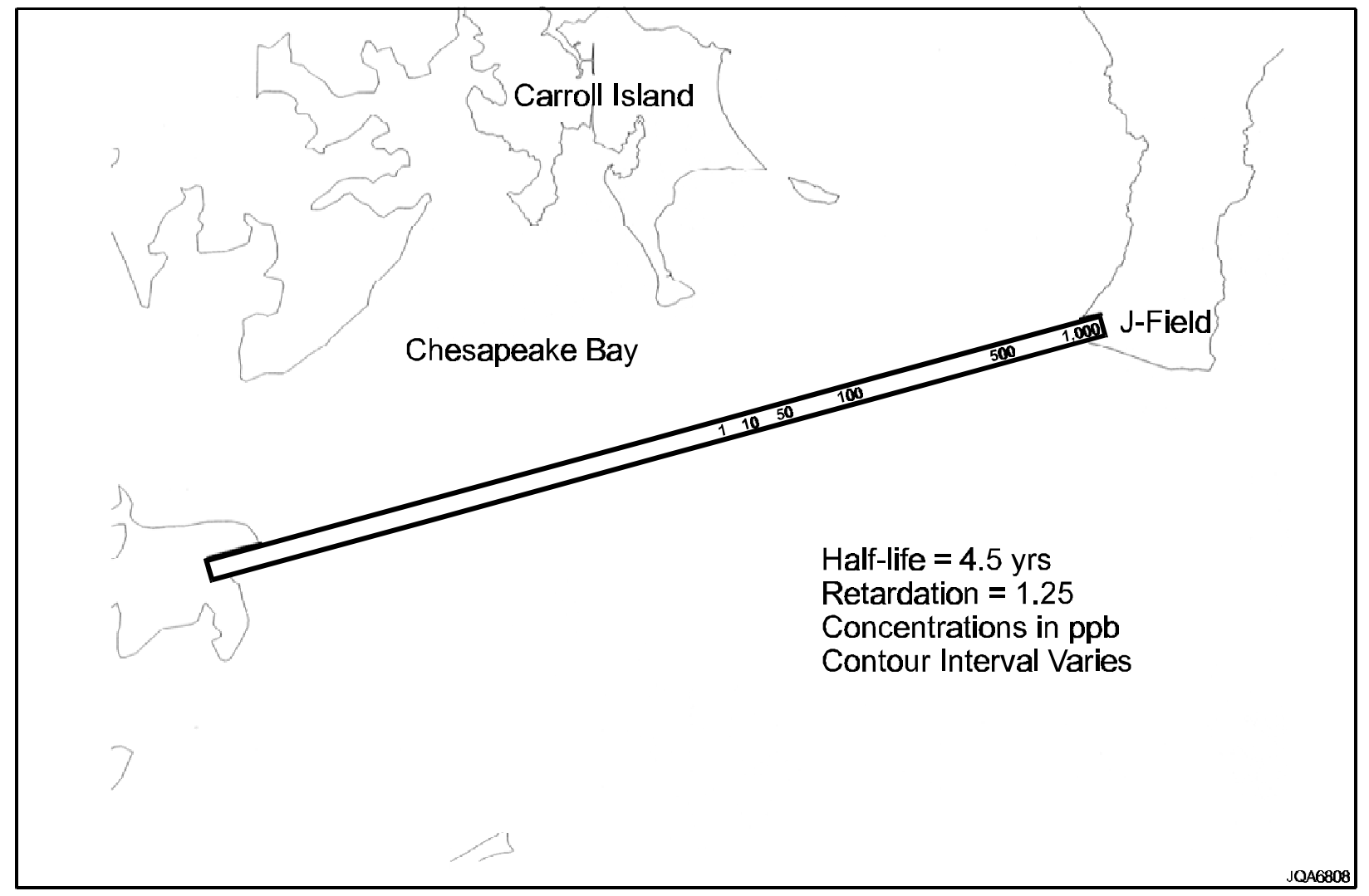

Figure 8 Base Case Transport Results for Simulated TCE Concentrations after 30 Years of Simulation 


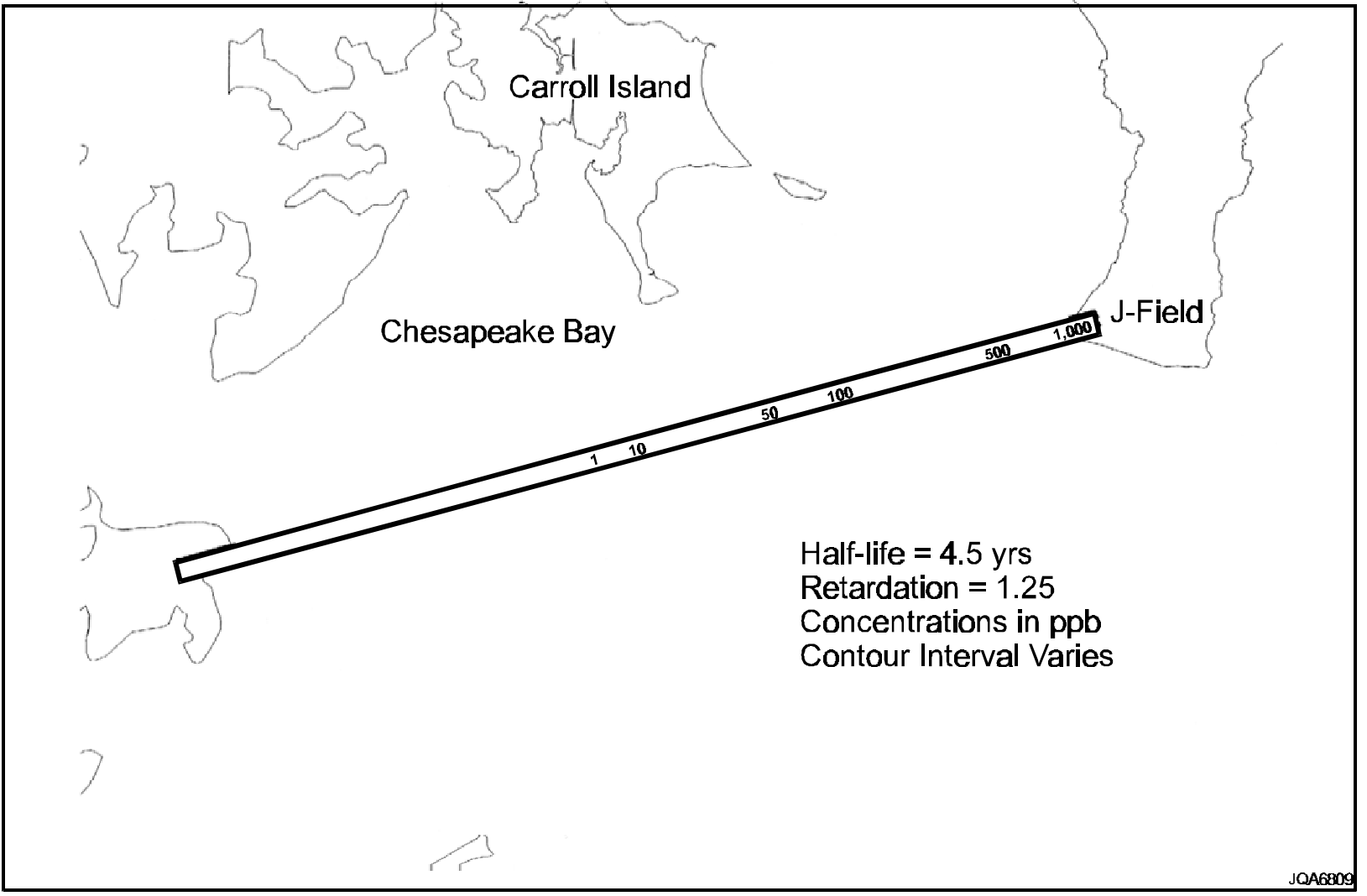

Figure 9 Base Case Transport Results for Simulated TCE Concentrations after 40 Years of Simulation 


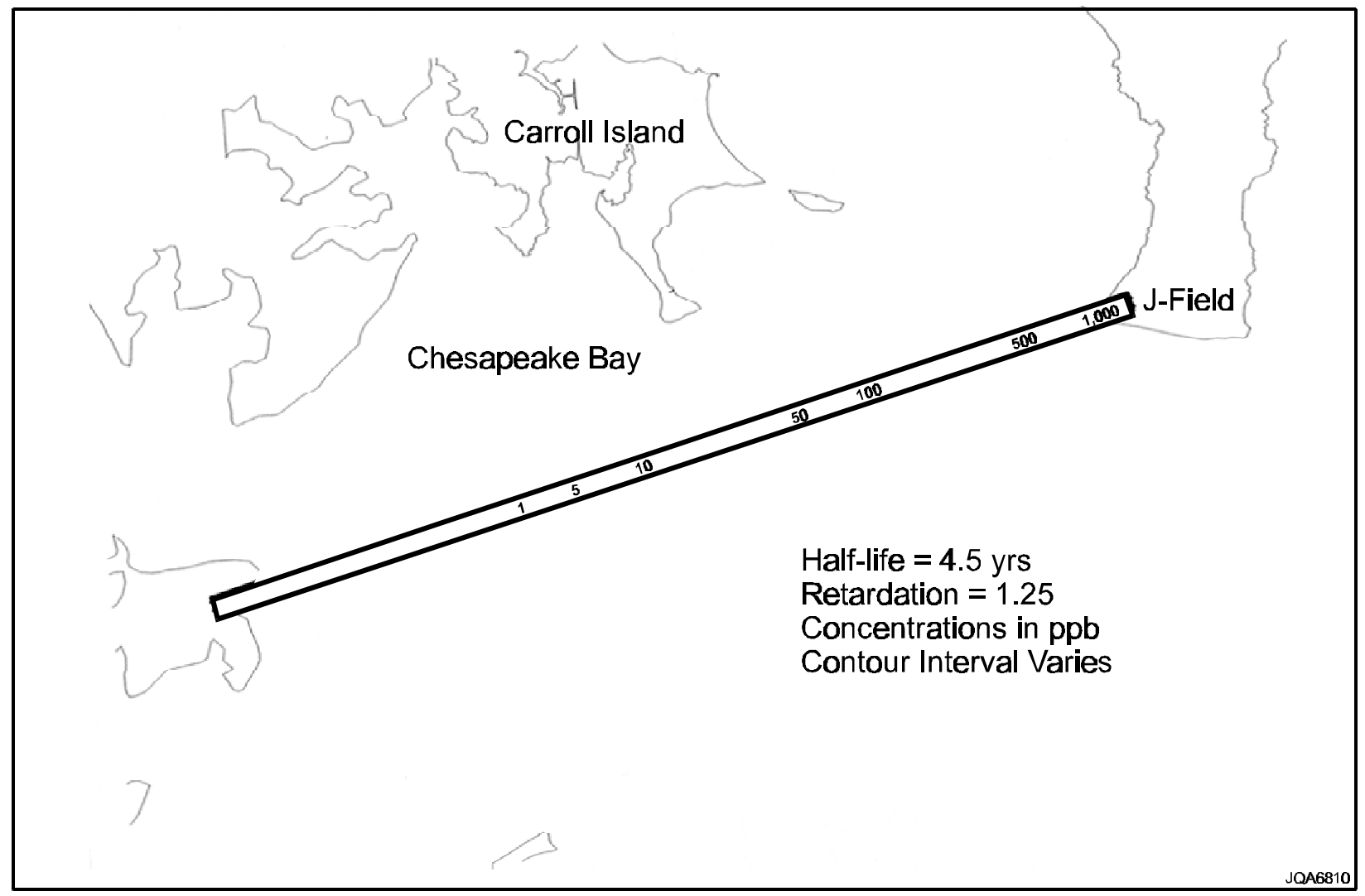

Figure 10 Base Case Transport Results for Simulated TCE Concentrations after 50 Years of Simulation 


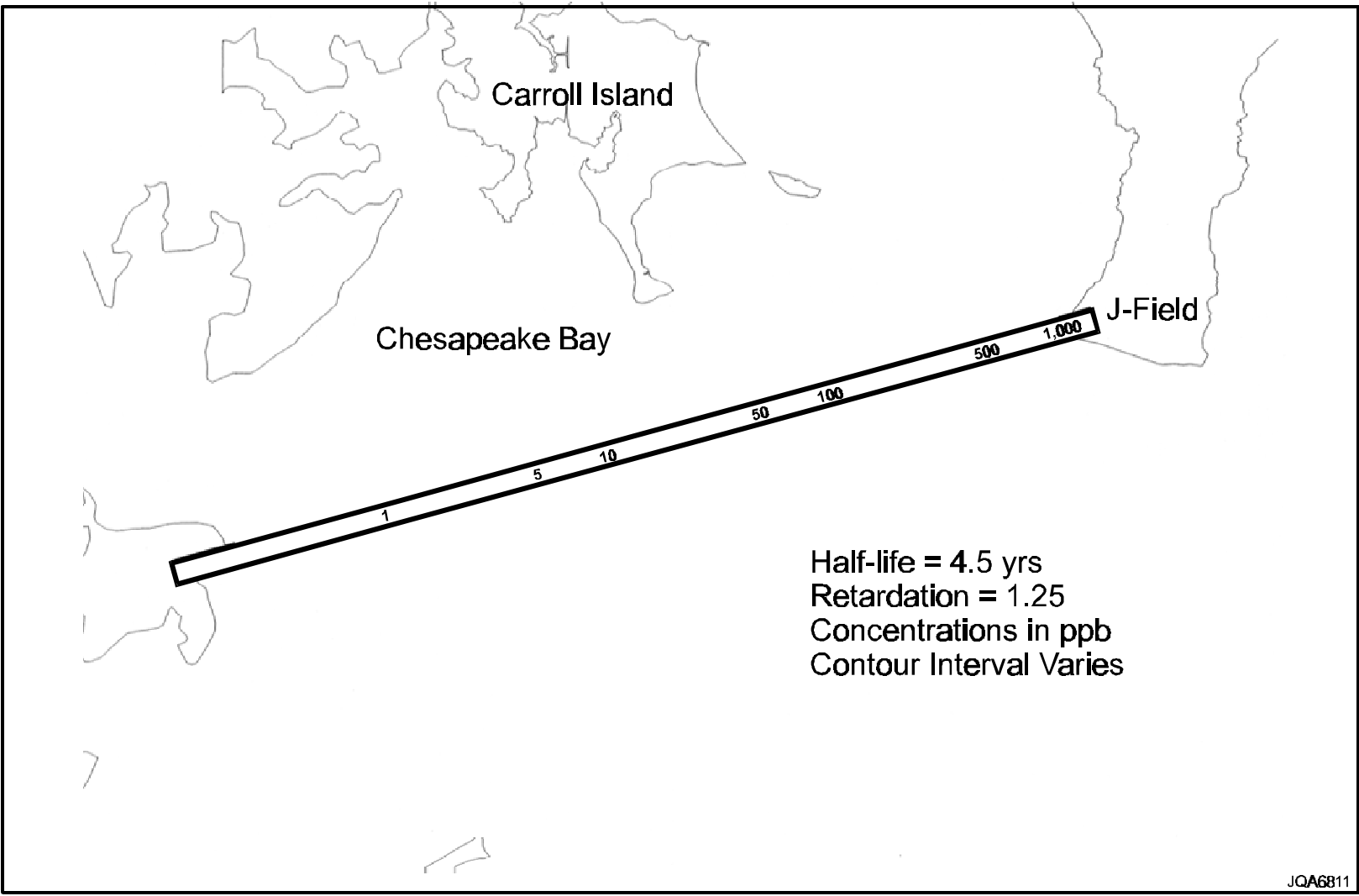

Figure 11 Base Case Transport Results for Simulated TCE Concentrations after Reaching Steady State at 60 Years of Simulation 


\section{Section 5 Discussion of Results}

A one-dimensional transport model with a continuous source, sorption, and firstorder decay can be expected to reach a steady state; the contaminant concentrations should decrease from the source value to essentially zero downgradient. The parameterdependent questions are

- How much time is needed before steady state is achieved?

- What is the distribution of concentrations once the plume has stagnated?

The results of this study indicate that the distance from the source to the hypothetical receptor is sufficient to overcome the relatively slow rate of biodegradation and low degree of sorption. In the base case, the 5-ppb contour is at steady state after less than 50 years of simulation.

The assumed first-order biodegradation rate equal to the slowest rate reported in the literature was sufficient to attenuate the plume before it could reach a receptor. The sensitivity of this parameter was apparent; when the rate was halved, significant concentrations reached the receptor. However, the likelihood of these concentrations actually reaching the receptor is negligible, because of the model's other simplifying assumptions.

Concentrations at any distant pumping well that could be affected by groundwater contamination beneath J-Field would be significantly lower than those predicted by this simplified one-dimensional model, because a pumping well would be drawing in clean water from other directions. This dilution effect was not considered in the simulations.

MT3D calculated a mass balance for each time step of each simulation. Each computer run in this study had a mass balance well below $1 \%$, which signifies that mass was conserved and that the results, from a computational standpoint, are accurate.

In this analysis, the degradation products were ignored. Although TCE degrades to $\mathrm{VC}$, which is highly toxic, VC also degrades to ethene/ethane. This preliminary modeling evaluation focused on whether TCE has a strong likelihood of reaching a receptor. Future work could address similar worst-case modeling of TCE and its degradation products (DCE, VC, ethene, ethane). 


\section{Section 6 Conclusions}

The results from highly conservative modeling indicated that groundwater contamination would have no impact on the nearest receptor. The model can therefore be a useful tool in proposing either a no action or a natural attenuation alternative for the confined aquifer, especially if source removal or other remedial actions are performed in the near-surface of the TBP area of J-Field.

The degradation rate in the confined aquifer beneath J-Field and along any possible pathway has not been measured. The decay rate may not follow a first-order model, and site-specific factors such as redox conditions will have a major influence on natural attenuation processes. However, complete biodegradation of TCE to ethene and ethane is believed to occur in the confined aquifer beneath J-Field on the basis of recent field sampling of natural attenuation indicators (Target Environmental Services, Inc. 1998).

Modeling included an extremely conservative direct flowpath to a hypothetical receptor, together with other conservative assumptions regarding the source strength, the sorptive capacity of aquifer materials, and flow rate. Mixing of groundwaters at the downgradient pumping well was ignored, as was the possibility of upward discharge to Chesapeake Bay. These assumptions may diminish the uncertainty in the rate of biodegradation of contaminants emanating from J-Field. 


\section{Section 7 References}

Barbee, G.C., 1994, "Fate of Chlorinated Aliphatic Hydrocarbons in the Vadose Zone and Ground Water," Ground Water Monitoring and Remediation 9(1):129-140.

Clement, T.P., 1997, RT3D: A Modular Computer Code for Simulating Reactive MultiSpecies Transport in 3-Dimensional Groundwater Aquifers, prepared by Pacific Northwest National Laboratory, Richland, Wash., for U.S. Department of Energy, Washington, D.C., Sept.

COE: See U.S. Army Corps of Engineers.

Cohen, R.M., and J.W. Mercer, 1993, DNAPL Site Evaluation, C.K. Smoley, Boca Raton, Fla.

Colman, S.M., et al., 1990, "Ancient Channels of the Susquehanna River beneath Chesapeake Bay and the Delmarva Peninsula," Geological Society of America Bulletin 102:1268-1279.

Cox, E., et al., 1995, "Intrinsic Biodegradation of Trichloroethene and Trichloroethane in a Sequential Anaerobic-Aerobic Aquifer," pp. 223-231 in Intrinsic Bioremediation, R.E. Hinchee, et al. (editors), Battelle Press, Columbus, Ohio.

deBruin, W.P., et al., 1992, "Complete Biological Reductive Transformation of Tetrachloroethene to Ethane," Applied and Environmental Microbiology 58(6): 1996-2000.

DiStefano, T.D., et al., 1991, "Reductive Dechlorination of High Concentrations of Tetrachloroethene to Ethene by Anaerobic Enrichment Culture in the Absence of Methanogenesis," Applied and Environmental Microbiology 57(8):2287-2292.

Draper Aden Environmental Modeling, Inc., 1996, BIOMOD 3-D software, Blacksburg, Va.

Drummond, D.D., and J.D. Blomquist, 1993, Report of Investigations No. 58:

Hydrogeology, Water-Supply Potential, and Water Quality of the Coastal Plain Aquifers of Harford County, Maryland, Maryland Geological Survey, Department of Natural Resources, Baltimore, Md.

Fetter, C.W., 1993, Contaminant Hydrogeology, Macmillan Publishing Company, New York, N.Y. 
Fleck, W.B., and D.A. Vroblesky, 1996, Simulation of Ground-Water Flow of the Coastal Plain Aquifers in Parts of Maryland, Delaware, and the District of Columbia: Regional Aquifer-System Analysis - Northern Atlantic Coastal Plain, Professional Paper 1404-J, U.S. Geological Survey, Washington, D.C.

Howard, P.H., et al., 1991, Handbook of Environmental Degradation Rates, Lewis Publishers, Chelsea, Mich.

Hughes, W.B., 1993, Hydrogeology and Soil Gas at J-Field, Aberdeen Proving Ground, Maryland, Water Resources Investigations Report 92-4087, U.S. Geological Survey, Towson, Md.

Lee, M.D., et al., 1995, "Intrinsic In Situ Anaerobic Biodegradation of Chlorinated Solvents at an Industrial Landfill," pp. 205-222 in Intrinsic Bioremediation, R.E. Hinchee, et al. (editors), Battelle Press, Columbus, Ohio.

Mackay, D., et al., 1993, Illustrated Handbook of Physical-Chemical Properties and Environmental Fate for Organic Chemicals: Volatile Organic Chemicals, Vol. 3, Lewis Publishers, Ann Arbor, Mich.

McDonald, M.G., and A.W. Harbaugh, 1988, "A Modular Three-Dimensional FiniteDifference Ground-Water Flow Model," in Techniques of Water Resources Investigations, Book 6, Chapter A1, U.S. Geological Survey, Reston, Va.

Montgomery, J.H., and L.M. Welkom, 1989, Groundwater Chemicals Desk Reference, Lewis Publishers, Chelsea, Mich.

Newell, C.J., et al., 1996, BIOSCREEN Natural Attenuation Decision Support System, Version 1.3, EPA/600/R-96/087, U.S. Environmental Protection Agency, Washington, D.C.

Otton, E.G., and R.J. Mandle, 1984, Hydrogeology of the Upper Chesapeake Bay Area, Maryland, with Emphasis on Aquifers in the Potomac Group, Report of Investigations No. 39, Maryland Geological Survey, Baltimore, Md.

Pankow, J.F., and J.A. Cherry, 1996, Dense Chlorinated Solvents and other DNAPLs in Groundwater, Waterloo Press, Guelph, Ontario.

Powars, D.S., 1997, Stratigraphy and Geophysical Logs from a Corehole Drilled to Bedrock at Robins Point, J-Field, Edgewood Area, Aberdeen Proving Ground, Maryland, Open-File Report 97-357, U.S. Geological Survey, Washington, D.C.

Quinn, J.J., et al., 1996, An Optimized Groundwater Extraction System for the Toxic Burn Pits Area of J-Field, Aberdeen Proving Ground, Maryland, ANL/EAD/TM-60, Argonne National Laboratory, Argonne, Ill. 
Remediation Technologies Development Forum, 1996, Guidance Handbook on Natural Attenuation of Chlorinated Solvents, prepared by the Bioremediation of Chlorinated Solvents Consortium of the Remediation Technologies Development Forum, Sept. (http://www.icubed.com/rtdf/html/public/bioremed/docs.html).

Rifai, H.S., et al., 1989, BIOPLUME II Computer Model of Two-Dimensional Contaminant Transport under the Influence of Oxygen Limited Biodegradation in Ground Water, Version 1.1, prepared for U.S. Environmental Protection Agency, Washington, D.C.

Target Environmental Services, Inc., 1998, Sampling and Mobile Laboratory Analysis of Natural Attenuation Parameters, Aberdeen Proving Ground - J-Field, Edgewood, Maryland, prepared for Argonne National Laboratory, Argonne, Ill., Jan.

Tenbus, F.J., and W.B. Fleck, 1996, Ground-Water Flow and the Potential Effects of Remediation at Graces Quarters, Aberdeen Proving Ground, Maryland, WaterResources Investigations Report 96-4044, U.S. Geological Survey, Towson, Md.

U.S. Army Corps of Engineers, 1997, Geology and Geomorphology of Aberdeen Proving Ground, Maryland, Draft, prepared for Directorate of Safety Health and Environment, Aberdeen Proving Ground, Md., Jan.

Wiedemeier, T.H., et al., 1996, Technical Protocol for Evaluating Natural Attenuation of Chlorinated Solvents in Groundwater, Air Force Center for Environmental Excellence, Brooks Air Force Base, San Antonio, Texas, Nov.

Wu, W.-M., et al., 1995, "Dechlorination of PCE and TCE to Ethene Using an Anaerobic Microbial Consortium," pp. 45-52 in Bioremediation of Chlorinated Solvents, R.E. Hinchee, et al. (editors), Battelle Press, Columbus, Ohio.

Yeh, H.C., and W.E. Kastenberg, 1991, "Health Risk Assessment of Biodegradable Volatile Organic Chemicals: A Case Study of PCE, TCE, DCE, and VC," Journal of Hazardous Materials 27:111-126.

Zheng, C., 1992, MT3D, A Modular Three-Dimensional Transport Model, Version 1.5, S.S. Papadopulos \& Associates, Inc., Bethesda, Md.

Zheng, C., and G.D. Bennett, 1995, Applied Contaminant Transport Modeling: Theory and Practice, Van Nostrand Reinhold, New York, N.Y.

Zoeteman, B.C.J., et al., 1981, "Persistency of Organic Contaminants in Groundwater, Lessons from Soil Pollution Incidents in the Netherlands," Science of the Total Environment 21:187-202. 